\title{
Of Coase and Cattle: Dispute Resolution Among Neighbors in Shasta County
}

\author{
Robert C. Ellickson*
}

\section{TABLE OF CONTENTS}

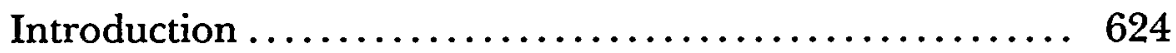

I. Shasta County and Its Cattle Industry ........ 629

A. Physical Environment................... 629

B. Social Environment....................... 632

C. Work Environment: Modes of Cattle Ranching ...... 636

1. The traditionalists .................. 637

2. The modernists ....................... 638

D. The Benefits and Costs of Boundary Fences ......... 640

II. The Politics of Cattle Trespass in the

NortheAstern Foothills ................... 643

A. Caton's Folly: The Closing of the Range at Round

Mountain .............................. 644

B. Caton's Repentance: The Defeat of the Oak Run Closure

Petition ................................ 647

1. Frank Ellis ..................... 647

- Robert E. Paradise Professor of Natural Resources Law, Stanford Law School.

My debts are many. Jerry Anderson, Thomas Hagler, and Keith Kelly were able research assistants. Participants in workshops at the Boston University, Harvard, Stanford, and Yale Law Schools provided helpful suggestions. Financial support was received from the Stanford Legal Research Fund, made possible by a bequest from the Estate of Ira S. Lillick, and by gifts from Roderick E. and Carla A. Hills and other friends of the Stanford Law School.

Dozens of people in Shasta County were of immeasurable assistance. I especially thank Bob Bosworth, the President of the Shasta County Cattlemen's Association, and Walt Johnson, the county Farm Advisor, for easing my immersion into Shasta County life.

A few stylistic notes are in order. Except for public figures, th : sames used are pseudonyms. To reduce clutter, and sometimes to protect privacy, I have generally refrained from footnoting references to individual interviews. The present tense usually denotes the situation in Shasta County in 1982, the year in which I conducted most of my interviews.

This article is part of a forthcoming book to be published by the Harvard University Press. The contents of the book are briefly described in text following note 161 infra.

(c) 1986 by Robert C. Ellickson. 
2. Ellis' antagonists .................... 648

3. Caton's mediation and the battle of petitions ..... 650

4. The hearing and its aftermath .............. 652

III. Research Methods ........................ 654

IV. The Resolution of Animal Trespass Disputes in

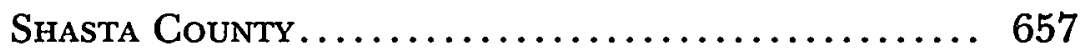

A. Animal Trespass Incidents ................. 657

B. Animal Trespass Law..................... 659

C. Knowledge of Animal Trespass Law ............ 667

1. Laymen's knowledge of trespass law ........... 668

2. Legal specialists' knowledge of trespass law....... 670

D. The Settlement of Trespass Disputes ............ 671

1. Norms, not legal rules, are the basic sources of entitlements ........................... 672

2. Incomplete enforcement: the live-and-let-live philosophy ......................... 673

3. The complexity of interneighbor relations: comprehensive mental accounts of who owes whom . 675

4. The control of deviants: the key role of self-help.... 676

V. Summary aND ImPlications $\ldots \ldots \ldots \ldots \ldots \ldots \ldots . \ldots 65$

"I think the whole thing is good neighbors. If you don't have good neighbors, you can forget the whole thing."

- Chuck Searle, Shasta County cattleman "My family believes in 'live and let live.' Have you heard of
that?"

This article reports the results of an investigation into how rural landowners in Shasta County, California, resolve disputes arising from trespass by livestock. The results provide an empirical perspective on one of the most celebrated hypothetical cases in the law-and-economics literature. In his landmark article, "The Problem of Social Cost," economist Ronald Coase invoked as his fundamental example a conflict between two neighbors-a rancher running cattle and a farmer raising crops. Coase used the Parable of the Farmer and the Rancher to illustrate what has come to be known as the Coase Theorem. This unintuitive proposition asserts, in its strongest form, that when transaction costs are zero, a change in the rule of liability will have no effect on the allocation of resources. For example, the Theorem

1. Coase, The Problem of Social Cost, 3 J.L. \& Econ. 1 (1960). 
predicts that as long as its admittedly heroic assumptions are met, the imposition of liability for cattle trespass would not cause ranchers to reduce the size of their herds, erect more fencing, or keep closer watch on their livestock. The Theorem has become the most fruitful, yet most controversial, proposition in law-andeconomics. ${ }^{2}$

Coase himself was fully aware that obtaining information, negotiating agreements, and litigating disputes are all potentially costly, and that thus his Parable might not portray accurately how rural landowners would respond to a change in trespass law. ${ }^{3}$ Some law-and-economics scholars, however, assume that transaction costs are indeed often trivial when only two parties are in conflict. ${ }^{4}$ Therefore, these scholars might assume that Coase's

2. Some recent landmarks in the Coase Theorem literature are Cooter, The Cost of Coase, 11 J. Legal Stud. 1 (1982); Hoffman \& Spitzer, The Coase Theorem: Some Experimental Tests, 25 J.L. \& Econ. 73 (1982); Regan, The Problem of Social Cost Revisited, 15 J.L. \& Econ. 427 (1972). A central theme of these articles is that Coase should have explicitly recognized the possibility that disputants may act strategically and thereby fail to carry out mutually advantageous exchanges. An unusually complete review of the literature is provided by Zerbe, The Problem of Social Cost in Retrospect, 2 Research in L. \& ECon. 83 (1980).

3. See Coase, supra note 1, at 15-19 (entitled "The Cost of Market Transactions Taken into Account").

Ronald Coase has in fact been a militant for the cause of empiricism. In recent years, he seems to have become increasingly frustrated with the sterility of the abstract debates over his Theorem:

[W] hile considerations of what would happen in a world of zero transaction costs can give us valuable insights, these insights are, in my view, without value except as steps on the way to the analysis of the real world of positive transaction costs. We do not do well to devote ourselves to a detailed study of the world of zero transaction costs, like augurs divining the future by the minute inspection of the entrails of a goose. Coase, The Coase Theorem and the Empty Core: A Comment, 24 J.L. \& Econ. 183, 187 (1981).

The central finding of the present work is that the residents of Shasta County often succeed, without the involvement of the state, in coordinating with one another in a mutually advantageous way. Coase's Parable of the Farmer and the Rancher sounds this same general theme of cooperative interaction. This finding is generally consistent with what Coase found in his own microscopic investigation of the supply of lighthouses in England. See Coase, The Lighthouse in Economics, 17 J.L. \& Econ. 357 (1974).

4. Several of Coase's colleagues at the University of Chicago wedded themselves to this assumption in the 1960s. See, e.g., W. Blum \& H. Kalven, Public Law Perspectives on a Private Law Problem: Auto Compensation Plans 58-59 (1965); Demsetz, Ithen Does the Rule of Liability Matter, 1 J. LEGaL STUD. 13, 16 (1972) (transaction costs "would seem to be negligible" when a baseball player negotiates with his club).

The current consensus, even among Chicagoans, is that negotiations in bilateral monopoly situations can be costly because the parties may act strategically. See, e.g., R. PosNer, EcoNOMIC ANalysis of Law 45 (2d ed. 1977); Cooter, Marks \& Mnookin, Bargaining in the Shadow of the Law: A Testable Model of Strategic Behavior, 11 J. LEGal Stud. 225, 242-44 (1982) ("The obstacle to agreement is the strategic nature of bargaining, not the cost of communicating"); Landes \& Posner, Salvors, Finders, Good Samaritans, and Other Rescuers: An Economic Study of Alliu- 
Parable faithfully depicts how rural landowners resolve cattletrespass disputes.

To explore the realism of the assumptions underlying the Farmer-Rancher Parable, I searched for a jurisdiction that had imposed varying rules of liability in cattle trespass situations and had changed those rules with some frequency. After briefly surveying a half-dozen candidates in California, I settled on Shasta County. Since 1945, a specific California statute has authorized the Shasta County Board of Supervisors, the county's elected governing body, to determine where in the county an owner of cattle is liable for damages stemming from unintentional cattle trespass on unfenced land. ${ }^{5}$ Although most of Shasta County is "open range"- territory where a cattleman is not liable for trespass damages of that sort-the Board has the authority to "close the range" in subareas of the county. A closed-range ordinance makes a cattleman strictly liable for any damage his livestock might cause while trespassing within the area affected by the ordinance. ${ }^{6}$ The Shasta County Board of Supervisors has exercised this power to close the range on dozens of occasions since 1945, thus changing the exact rule of liability that Coase used in his famous example. ${ }^{7}$ I traveled to Shasta County to determine whether these legal changes had had any impact. ${ }^{8}$

ism, 7 J. LeGAL STUD. 83, 91 (1978) ("transaction costs under bilateral monopoly are high"). See also sources cited at note 2 supra.

5. See notes 99-103 infra and accompanying text.

6. The terms "closed-range" and "open-range" can be a source of confusion. I use the terms throughout this article as they are ordinarily used in Shasta County, to denote the legal regime applicable to a particular territory. The potential confusion arises because the terms might be construed as indicating a method of husbandy - that is, whether in a particular area it is the custom of cattlemen to run their animals at large or to keep them behind fences. In Shasta County, the correlation between legal regime and method of husbandry is rather weak. For example, most ranchers in the open-range areas of the county keep their herds behind fences.

7. To invoke Calabresi \& Melamed's fruitful typology, a closed-range ordinance essentially shifts the legal regime from property-rule protection of the rancher to liability-rule protection of the trespass victim. See Calabresi \& Melamed, Property Rules, Liability Rules, and Inalienability: One View of the Cathedral, 85 Harv. L. Rev. 1089, 1 105-1115 (1972). Hoffman \& Spitzer, supra note 2 , at 84 , deserve credit for noting that Coase had contrasted asymmetrical legal positions. But $c$. note 112 infra and accompanying text (noting the availability of injunctive relief to trespass victims in closed range).

8. A number of other law and economics scholars have investigated empirically the impact of transaction costs on interneighbor coordination. See, e.g., Cheung, The Fable of the Bees: An Economic Investigation, 16 J.L. \& Econ. 11 (1973); Crocker, Externalities, Property Rights, and Transactions Costs: An Empirical Study, 14 J.L. \& Econ. 451 (1971). The study closest to mine in its substantive focus, although not its methodology, is Vogel, The Effect of Changes in Property Rights Entitlements on Production: The Coase Theorem and California Animal Trespass Law, $15 \mathrm{~J}$. LEGAL. 
This study presents findings that cast doubt on many of the assumptions undergirding the Coasean Parable. It also strives to help bridge the chasm lying between the law and economics and law and society movements, ${ }^{9}$ perhaps the two most significant social-scientific schools of legal research. On the whole, the law and society scholars have gathered the better field data on dispute resolution practices, and the law and economics scholars have developed the more explicit, rigorous, and testable theories of human behavior. Although one might think that members of these two schools would perceive irresistible benefits from collaboration, these two groups have worked largely in isolation from one another. They have separate journals. ${ }^{10}$ They gather at separate conferences. They rarely read, much less cite, work by scholars in the other camp. This absence of cross-fertilization stems not only from lack of familiarity with the working language of the other group, but also from a mutual lack of respect, even a contempt, for the kind of work that the other group does. To exaggerate only a little, the law and economics scholars believe that the law and society group is deficient in both sophistication and rigor, and the law and society scholars believe that the law and economics group is not only out of touch with reality but also short on humanity.

In conducting this study, I placed a foot squarely within each of the two camps. Law and economics, the tradition within which I have mainly labored, provided the Parable that inspired the study. By undertaking "microscopic" 1 field research into the

STuD. - (1986) (forthcoming) (regression analysis of effects of various closed-range ordinances on agricultural production in California counties between 1850 and 1877).

In recent years Elizabeth Hoffman and Matthew Spitzer have been the most persistent and creative transaction cost empiricists. See, e.g., Hoffman \& Spitzer, supra note 2 (report on a series of laboratory experiments in which subjects could achieve gains by cooperating); Spitzer \& Hoffman, A Reply to Kelman's "Consumption Theon', Production Theory, and Ideology in the Coase Theorem," 53 S. CAL. L. REv. 1187 (1980) (study of the effect of the elimination of the Reserve Clause on the movement of baseball players between clubs).

9. Any discussion of a chasm between academic subcultures brings to mind C.P. Snow's classic 1959 lecture on "The Two Cultures." Snow used as his polar opposites literary intellectuals and physical scientists, and speculated on whether social scientists represented yet a third culture. C.P. Snow, The Two Cultures: ANd A Second Look 70-71 (1964). The chasm that I identify is a division between groups of social scientists. It suggests that Snow was understandably in a quandary about how to classify members of the social scientific disciplines.

10. The core journals are the JouRnal of LAw AND Economics and the LAw \& SociETy REVIEW.

11. I borrow the term "microscopic" from Clifford Geertz, an anthropologist noted for his devotion to "thick descriptions" of human interaction. See, e.g., C. GeErTz, The InTERPretation of Cultures 3-30 (1973). 
resolution of a narrow class of disputes, however, I followed the methods of pioneering law and society scholars such as Stuart Macaulay and H. Laurence Ross. ${ }^{12}$ After reading in both literatures, I confess my disloyal suspicion that law and society scholars would generally be more successful than law and economics scholars in predicting the essentials of the story to come.

The Shasta County evidence indicates that Coase's FarmerRancher Parable correctly anticipates that a change in the rule of liability for cattle trespass does not affect, for example, the quality of fences that separate ranches from farms. The Parable's explanation for the allocative toothlessness of law is, however, exactly backward. The Parable's explanation is that transaction costs are low and that parties respond to a new rule by agreeing to an exchange of property rights that perpetuates the prior (efficient) allocation of resources. The field evidence I gathered suggests that a change in animal trespass law indeed fails to affect resource allocation, not because transaction costs are low, but because transaction costs are high. Legal rules are costly to learn and enforce. Trespass incidents are minor irritations between parties who typically have complex continuing relationships that enable them readily to enforce informal norms. The Shasta County evidence indicates that under these conditions, potential disputants ignore the formal law. As Coase probably suspected, ${ }^{13}$ the Para-

12. In preparing his classic article, Non-Contractual Relations in Business: A Preliminary Study, 28 Am. Soc. Rev. 55 (1963), Macaulay interviewed business executives and lawyers to find out how Wisconsin manufacturing firms resolve contractual disputes. Ross' best known work is H. Ross, SeTtled OUt of Court (rev. ed. 1980), which describes how insurance adjusters process claims covered under automobile liability policies. Notable also is Ross \& Littlefield, Complaint as a Problem Solving Mechanism, 12 LAw \& Soc'y REv. 199 (1978), a study of how a large appliance retailer in Denver handles consumer complaints.

Law and society scholars have done relatively little field work on dispute resolution between adjoining landowners. But see, e.g., Baumgartner, Social Control in Suburbia, in 2 Toward a General Theory of Social Control 79 (D. Black ed. 1984); Ruffini, Disputing over Livestoch in Sardinia, in The Disputing Process: Law in Ten Societies 209 (L. Nader \& H. Todd eds. 1978) (finding that shepherds in Sardinia rely on self-help, not formal legal processes, to resolve rustling disputes). Economists have also done little field work on relations among neighbors. But see sources in the first paragraph of note 8 supra.

There is a broad interdisciplinary perception that progress in understanding conflict resolution depends upon more low-level empirical work. See, e.g., R. Hardin, Collective AcTION 229-30 (1982) (comments of a philosopher-game theorist). See also Felstiner, Influences of Social Organization on Dispute Processing, 9 Law \& Soc'y Rev. 63, 86 n.28 (1974) ("Ironically, we have better data about dispute processing in Indian villages, Mexican towns, and East African tribes than we have about that process in American communities." (comments of a law-andsociety scholar)).

13. See note 3 supra and accompanying text. 
ble of the Farmer and the Rancher therefore ill-describes how rural landowners actually interact with one another.

Part I of this article introduces the relevant residents of Shasta County and their techniques of cattle ranching and boundary fencing. Part II narrates the political history of the two closed-range battles that occurred in the area where the study was conducted. Part III explains why I chose this area to study and my field research methods. Part IV, the heart of the article, describes how the rural residents of Shasta County resolve their cattle-trespass disputes. Finally, Part V summarizes the article's principal findings and implications.

\section{Shasta County and Its Cattle Industry}

\section{A. Physical Environment}

Shasta County lies at the northern end of the 400 mile-long Central Valley of California. The Sacramento River, which drains the northern half of the Central Valley, bisects the county. Redding, Shasta County's county seat and largest city, is situated at an elevation of 500 feet at the spot where the Sacramento River emerges from the mountains north of the Valley to begin its trip south toward San Francisco Bay. High mountain peaks lie within sight of Redding in all directions except south. The Trinity Mountains lie to the west; the towering cone of Mount Shasta stands fifty miles due north, in Siskiyou County; and to the east lie other peaks of the volcanic Cascade Range- notably Mount Lassen, which sits in Shasta County's southeastern corner. To the east, north, and west of Redding, foothills rise irregularly toward these distant mountain peaks.

Weather dictates Shasta County's ranching practices. Like the rest of California, the county has a wet season and a dry season. Redding receives an average annual rainfall of 38.74 inches, most of it concentrated in the winter months. ${ }^{14}$ Little rain falls between mid-May and November. During the summer months intense sunlight bakes Redding, and the surrounding mountains block cooling winds. ${ }^{15}$ In the spring, the grasslands near Redding are green from the heavy winter rains; by summer, the extreme heat has turned the groundcover brown.

Most of Shasta County's terrain is too mountainous and its

14. Record Searchlight (Redding, Cal.), Aug. 11, 1982, at 15, col. I.

15. In July, the city's average daily high temperature is 98 degrees. Id. at 14 , col. 3. 
soils too poor to support significant agricultural activity. The majority of the land area in the county is commercial-quality forest, most of which the United States Forest Service and a handful of private timber companies own. ${ }^{16}$ Census data describe sixteen percent of the county as "land in farms." 17 The bulk of this agricultural land is unirrigated and used only as seasonal pasture for livestock-principally cattle, the county's major agricultural product. Only one percent of the county's land is used for raising harvested crops, ${ }^{18}$ and a majority of this field-crop acreage is devoted to alfalfa or other hay grown as livestock feed.19

In 1973, the Shasta County Board of Supervisors voted to "close the range" in a fifty-six square-mile rectangle of territory around Round Mountain, a rural hamlet situated thirty miles northeast of Redding. This ordinance, which county cattlemen now call "Caton's Folly" to embarrass a supervisor who helped pass it, provided the best opportunity in Shasta County to test the effects of an actual change in the rule of liability for cattle trespass. Nine years later, in 1982, the Board of Supervisors considered, but rejected, a petition to close the range in the Oak Run area immediately southwest of Caton's Folly. ${ }^{20}$ The Oak Run controversy promised to reveal the effects of a threatened change in liability rules. Residents of the Oak Run and Round Mountain areas were interviewed to shed more light on these effects. The general area northeast of Redding-what I call the Northeastern Sector-thus warrants closer description.

The Northeastern Sector consists of three ecological zones: grassy plains, foothills, and mountain forest. The elevation of the land largely determines the boundaries of these zones; the higher the terrain, the more rain it receives, and the cooler its summer weather.

The zone between 500 and 1500 feet in elevation, the zone

16. Of the 2.4 million acres of land in Shasta County, 1.3 million have been identified as “commercial forest." Cal. Dep't of Finance, Cal. Statistical Abstract 2, 129 (1983). The United States Forest Service owns $35 \%$ of this commercial forest, and forest industry companies own $46 \%$. Id. at 129 .

17. Id. at 111 (citing data from the 1978 U.S. Census of Agriculture).

18. Id. at 2,111 .

19. E. Peterson, In the Shadow of the Mountain: A Short History of Shasta County, California 110 (1965).

Coase's Parable involves a pasture adjoining a field of annually harvested crops. These land uses are rarely contiguous in Shasta County. The lessons of the Parable, however, in no way depend on how the Rancher's neighbor uses his land.

20. See notes 70-76 infra and accompanying text. 
FIGURE 1

MAP OF NORTHWESTERN CALIFORNIA

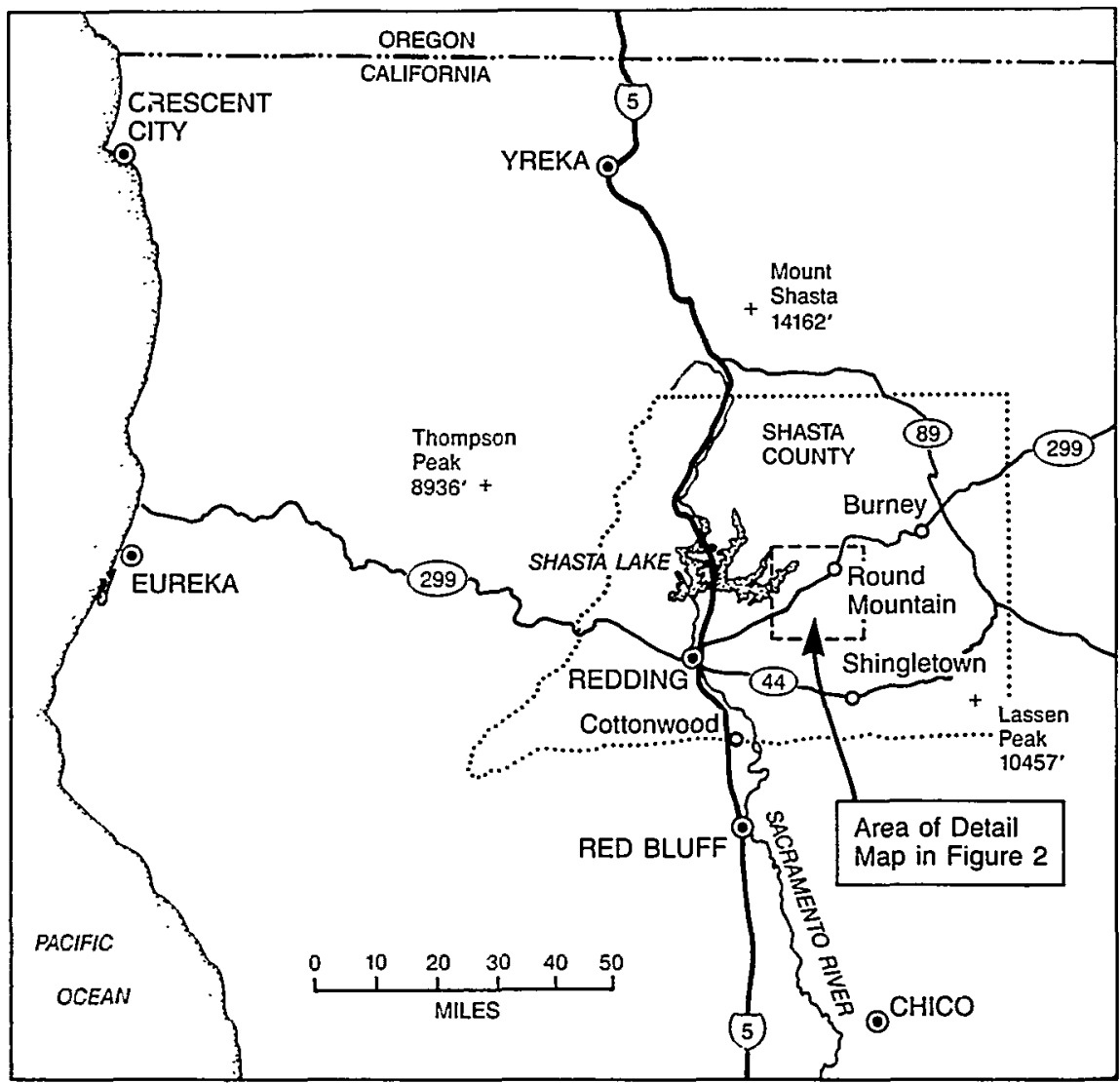

closest to Redding, consists of grassy plains. This idyllic, oakdotted country provides natural pasture during the spring and, if irrigated, can support a herd year-round. A water supply adequate for irrigation is available, however, only near the streams that flow through the area. Moreover, the soil in much of the grassy plains is infertile hardpan. Because of these natural constraints, the full-time ranchers who operate in this zone typically need at least several square miles of pasture.

The foothills lie between 1500 and 3500 feet in elevation. Both Caton's Folly and the Oak Run area fall within this transition zone. Much of the foothill area has a mixed natural treecover of pine and oak. In open areas the natural ground cover is less likely to be grass than an unpalatable chaparral of manzanita, buckbrush, and like shrubs. To foothill ranchers this 
brush is almost as repulsive a thought as the importation of Australian beef; the more enterprising foothill ranchers spend much of their energies grappling with this foe. ${ }^{21}$

Mountain forest, the third zone, starts at about 3500 feet. Ponderosa pine, douglas fir, and other conifers that have supplanted the deciduous oaks cover the mountainsides at this elevation. The mountain forests remain green year-round, but most are too cold in winter and too hard to clear to be suitable sites for cattlemen's base ranches. The Roseburg Lumber Company owns much of the mountain forest in the Northeastern Sector. ${ }^{22}$ Like other private timber companies in the county, Roseberg has not shown any interest in subdividing its lands for development. For many decades, however, Roseberg and its predecessors in ownership have leased their forests to Shasta County cattlemen for summer range.

\section{B. Social Environment}

The volatility of population change may affect how people resolve their disputes. Shasta County has experienced rapid population growth. Between 1930 and 1980, the number of county residents increased ninefold, ${ }^{23}$ and in the decade from 1970 to 1980 , total County population rose from 78,000 to $116,000 .^{24}$ The County's population growth rate of 49.0 percent in the 1970 's was substantially higher than the overall state rate (18.5 percent), and was somewhat higher than the aggregate rate for California's nonmetropolitan counties (36.4 percent). ${ }^{25}$ Redding's location at the northern end of the Central Valley makes it a natural transportation hub. It serves as the gateway to moun-

21. See text accompanying note 46 infra.

22. The Roseburg Lumber Company is a closely held corporation based in Roseburg, Oregon. It is controlled by Kenneth Ford, a self-made man whom Forbes Magazine has listed as one of the forty wealthiest persons in the United States. San Francisco Chron., Aug. 28, 1982, at 14, col. 4. When Roseburg purchased its forests in the Northeastern sector in 1979 from the Kimberly-Clark Corporation, it became the fourth timber company to own these lands since the early 1940s.

23. In 1930, the County's population was 13,927. U.S. Dept. OF Commerce, Bureau of the Census, 15th Census of the United States, vol. 3, pt. 1, at 284 (1932).

24. U.S. Dept. of Commerce, Bureau of the Census, 1980 Census of Population, vol. 1, pt. 6, ch. A, table 4 (1982). In 1980, 42,000 people lived in the city of Redding. Id. By 1984, the city's estimated population exceeded 50,000, and Shasta County achieved the status of a Standard Metropolitan Statistical Area.

25. Calculated from data in the 1980 Census of Population. 
FIGURE 2

MAP OF THE OAK RUN/ROUND MOUNTAIN AREA

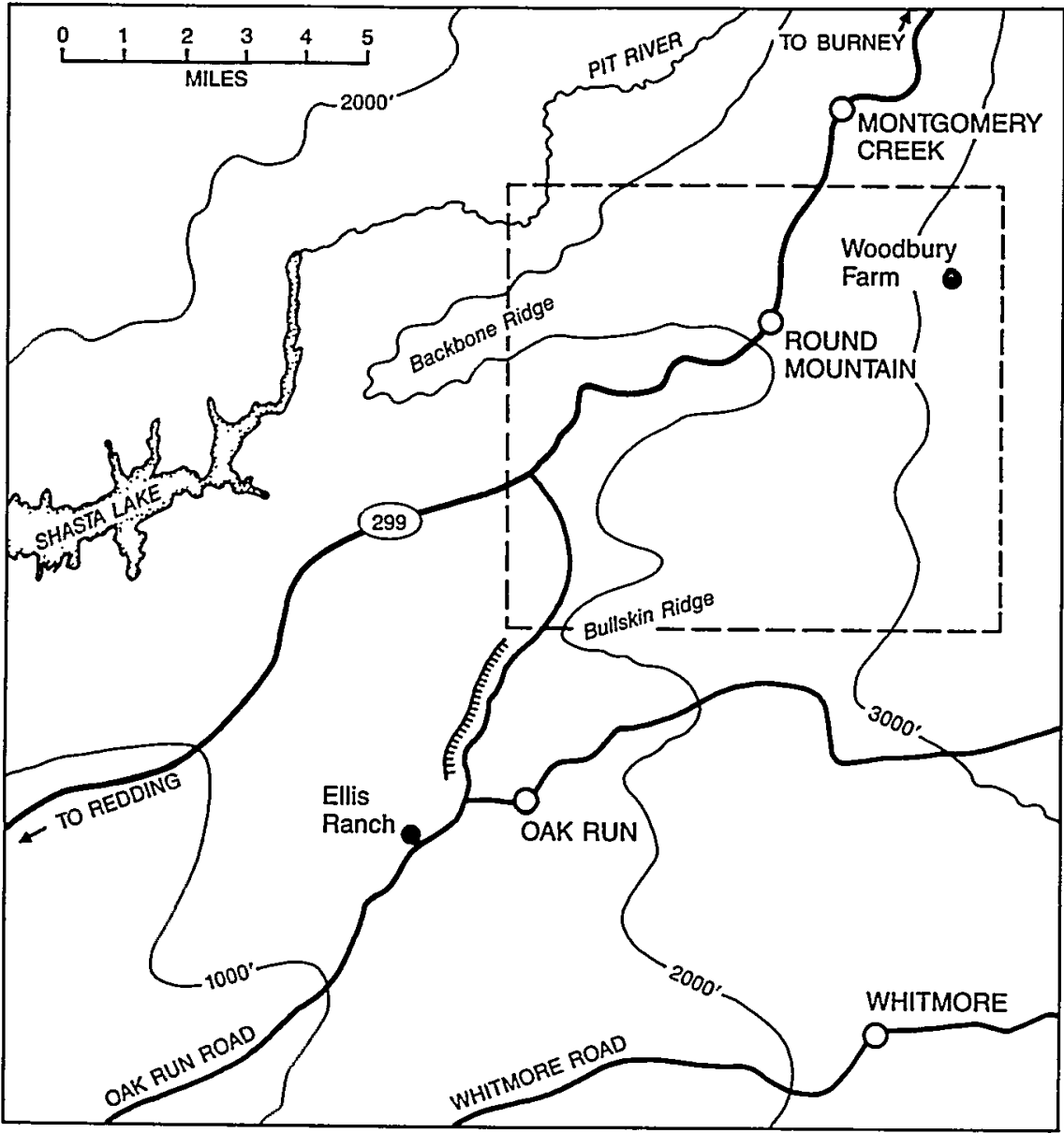

- - Boundary of Caton's Folly

Tmmmm Fence that Ellis Built at Caton's Request

tain recreation areas lying in three directions, and it has emerged as the major regional center on Interstate 5 between Sacramento, California, and Eugene, Oregon. Many migrants to Shasta County have come from the San Francisco and Los Angeles areas. Indications of social instability have accompanied the influx of migrants. In 1981, Shasta had the highest divorce rate of any county in California, ${ }^{26}$ and in 1980 , the county's unemployment

26. In 1981, Shasta County had 8.7 dissolutions and nullities of marriage per 1,000 estimated persons, compared to a statewide figure of 5.8 per thousand. STATE OF (ANI.., DEP'T of Health Servs., Vital Statistics of California-1981, at 128 (1983). 
rate was twice that of the state as a whole. ${ }^{27}$

Precise figures on population trends within the Northeastern Sector are not available. It appears, however, that during the 1970 s, the Sector's population grew by an even larger percentage than did the county's. ${ }^{28}$ Not surprisingly, the recent demographic histories of the three ecological zones within the Sector are rather different.

Residential patterns in the grassy plains have not changed much in recent years. Beyond the suburbs of Redding most of the acreage in the grasslands and lower foothills remains divided into ranches at least several square miles in size. Approximately half of these ranches are owned by descendants of families that have been in the county for several generations. ${ }^{29}$ Although many of these ranches have a current market value of $\$ 1,000,000$ or more, the ranchers typically have modest annual incomes. For decades, ranchlands in Shasta County have generated an annual cash return of only one or two percent of market value. ${ }^{30}$ The cattlemen who own and operate the large family ranches tend to

27. Census data put the County's unemployment rate at $13.8 \%$, compared to the state's 6.5\%. U.S. Dep't of Commerce, Bureau of the Census, 1980 Census of Population and Housing, Advance Estimates of Social, Economic, and Housing Characteristics. The timber industry, an important factor in the Shasta County economy, was in a deep slump in 1980, a factor that no doubt contributed to this disparity.

28. The population of what the Census Bureau calls the Central Shasta division increased from 3,049 in 1970 to 6,784 in 1980, or by $122 \%$. U.S. DEP'T OF CoMMERCE, BUREAU of the Census, 1980 Census of Population, vol. 1, pt. 6, ch. A, table 4, n.41 (1982). This division includes both the Northeastern Sector and larger rural territories to the north, south, and southeast.

29. The first pioneers to settle east and northeast of Redding used the grasslands and lower foothills to raise livestock. The descendants of the nineteenth century pioneer families-Coombs, Donaldson, Wagoner-still hold a special place in rural Shasta County society. Oldtimers are quick to identify their roots in the county, and sometimes refer to families who arrived a generation ago as "people who haven't been here very long."

Prior to the 1920s, the Southern Pacific Railroad owned alternate sections in the grassy plains-a reward from the United States for laying track to Redding. The government grant consisted of alternate sections for a distance of 20 miles on both side of the track. S. DAGGetT, Chapters on the History of the Southern Pacific 50, 122 (1922). During the 1920s, the Southern Pacific sold off most of its grassland sections at the then market price of $\$ 2.50$ to $\$ 5.00$ per acre, thereby enabling the pioneer ranching families to consolidate their holdings. Abandoning their prior practice of running their herds at large, these families erected fences around their multi-thousand-acre spreads, cleared patches of brush, and began to irrigate their better pastures.

30. Interview with Robert Shaw, Redding-based appraiser (July 19, 1982). Mr. Shaw attributed the low returns to tax benefits and psychic income that ranching confers.

Cattle ranching is noted for skimpy financial returns. See Arthur D. LitTle, Inc., Final Environmental Statement, Proposed livestock Grazing Program, BlM Cerbat/Black Mountain Planning Units II-139 to -142 (1978) (returns to cattle ranching in Arizona range 
follow self-imposed seven-day-a-week work schedules and live in houses less imposing than those one would find in an average American suburb. When estate taxes or property taxes have squeezed them financially, ranching families have either conveyed their entire holdings to other ranchers or to investors seeking tax shelters or, more commonly, they have sold tree-covered pieces of their ranches to developers for subdivision into ranchettes.

The foothills have seen more subdivision activity and absolute population growth than have the grassy plains. Both supply and demand conditions explain this pattern. Because the foothills are somewhat less suited than the grasslands for agriculture, foothill landowners are more likely to consider subdividing their holdings. Most homebuyers would also prefer the foothills to the grasslands as a residential location because the higher elevations are cooler in summer and offer more tree cover. As a result, the foothills within commuting distance of Redding have experienced a multifold increase in population over the past twenty years. ${ }^{31}$

Many of the recent settlers in the foothills are either retirees or younger migrants from California's major urban areas. These newcomers tend to live on minimally improved lots of from five to forty acres, either in owner-built houses or mobile homes. Many of these ranchettes have sprung up near hamlets, such as Oak Run and Round Mountain, that contain a general store, a post office, an elementary school, and other basic community facilities. Despite these clusters of growth, development in the foothills has been rather diffuse. Especially since the mid-1960s, small-scale real estate operatives have subdivided forested areas in every sector of the foothills. ${ }^{32}$ Thus virtually all foothill ranch-

from negative to a positive one to two percent; ranchers do it for love); Charlier, Home on the Range is a Part-Time Deal for Many Cowboys, Wall St. J., Jan. 8, 1985, at 1, col. 4.

31. Some of the new development has been for second homes. Celebrities such as baseball pitcher Vida Blue, actor Clint Eastwood, country singer Merle Haggard, and ex-Congressman Pete MicCloskey are among those who have purchased properties in the rural areas east of Redding.

32. John Williams of the Redding office of the Title Insurance \& Trust Co. generously permitted me to use the firm's tract indexes. These indexes showed that in 24 sections near the southern border of Caton's Folly, the number of land parcels increased from 61 in 1930 , to 145 in 1972 , to 295 in 1982.

Countywide, the number of land parcels quadrupled between 1967 and 1982. Interview with Tony Estacio, Chief, Administrative Services, Assessor's Office of Shasta County (July 8, 1982). These recent rates of parcelization appear atypically high for rural land markets. See 
ers have some ranchette owners as neighbors. Ranchette owners may keep a farm animal or two as a hobby, but few of them make significant income from agriculture. The ranchette owners nevertheless admire both the cattlemen and the folkways traditionally associated with rural Shasta County.

\section{Work Environment: Modes of Cattle Ranching}

Despite their long hours of work, few ranchers in Shasta County find raising beef cattle a road to prosperity. The typical rancher runs a cow and calf operation. When his calves are seven to twelve months old, he ${ }^{33}$ trucks them a dozen miles south of Redding to the Shasta County Auctionyard at Cottonwood, where each Friday some 3,000 head change hands. Agents for feedlot operators and pasture owners buy the calves, take them to feedlots and pastures outside the county, and feed and fatten them for a few months to prepare them for slaughter. In 1982, a six-hundred pound yearling sold at auction in Cottonwood for about $\$ 375$, compared to the $\$ 500$ it would have brought in 1979 , the year that nominal beef prices peaked. ${ }^{34}$ Not only have beef prices recently failed to match the rate of inflation, but in the 1970s per capita consumption of beef in the United States began to fall. ${ }^{35}$ Shasta County is at best marginal cattle country, and some cattlemen there understandably fear that they may be among the casualties in their beleaguered industry's continuing shakeout.

Shasta County cattlemen may be loosely grouped into two categories: the traditionalists and the modernists. ${ }^{36}$ Traditional-

R. Healy \& J. Short, The Market For RuRal LaNd 22 (1976) (in only one of five counties studied did the number of rural land parcels double between 1954 and 1976).

33. Although women own, manage, and provide most of the physical labor on a number of the ranches in Shasta County, rural culture generally supports the differentiation of sex roles. Thus a woman rancher who wishes to be active in the county Cattlemen's Association is likely to participate only in the CowBelles, the women's auxillary. The National Cattlemen's Association did recently elect its first woman president, JoAnn Smith, but she had come to prominence by serving as president of the Florida CowBelles. N.Y. Times, Apr. 24, 1985, at $\mathrm{Cl}$, col. 1 .

34. See San Francisco Chron., Aug. 26, 1982, at 38, col. 2.

35. Per capita beef consumption peaked at $95.7 \mathrm{lbs}$. in 1976 , and by 1981 had fallen to 78.3 lbs., as consumers shifted toward poultry and pork. N.Y. Times, Aug. 9, 1981, § IV, at 22 , col. 3.

36. These categories inevitably oversimplify. For example, Dick Coombs and Chuck Searle employ modernist land-management and husbandry practices, yet continue the traditionalist practice of leasing mountain forest for summer range. 
ists tend to be more marginal economically, and have a greater stake in fighting "closed range" ordinances.

\section{The traditionalists.}

Traditional Shasta County cattlemen continue to follow the husbandry practices that were nearly universal in the county as late as the 1920s. A traditionalist's trademark is that he lets his cattle roam, essentially untended, in unfenced mountain areas during the summer. ${ }^{37}$ This customary practice evolved in response to the severity of Shasta County's dry season. In the area northeast of Redding, a rancher lacking irrigated pasture needs about ten to twenty acres per animal unit ${ }^{38}$ for winter and spring pasture. Thus, to support 200 cattle-a substantial herd by Shasta County standards-a rancher without irrigated pasture needs at least 2,000 acres, or just over three square miles of land. During the dry season the brutal heat makes unirrigated grasslands almost worthless. To feed his animals during the summer, a lowland cattleman must therefore either have access to irrigated pasture or be able to move his animals to the high foothills and mountains where cooler dry season temperatures enable natural forage to survive. The traditionalist solution is a summer grazing lease on a large tract of mountain forest.

The United States Forest Service, the Bureau of Land Management, ${ }^{39}$ and major private timber companies, have regularly entered into grazing leases with county cattlemen. Although the timber company grazing leases typically have only a one-year term, the companies have allowed cattlemen to renew them as a matter of course. ${ }^{40}$ Federal leases may run for any period up to

37. The classic study of cattlemen operating on unfenced range is $E$. OsGood, THE DAY of THE CATTLEMAN (1929) (emphasizing practices in Wyoming and Montana during the latter part of the Nineteenth Century). On the history of traditionalist practices in California, see R. Cleland, The Cattle on a Thousand Hills (2d ed. 1951); D. Dary, Cowboy Culture 44-66 (1981).

38. An "animal unit" is a mature cow plus calf, or the equivalent in terms of forage consumption. A horse converts to 1.25 animal units, a sheep to 0.2 animal units, and so on. An "animal unit month" (AUM) is the amount of forage an animal unit consumes in one month of grazing. H. Heady, Rangeland Management 117 (1975).

39. These two agencies manage most of the vast federal holdings in the county. Altogether, federal agencies own $42 \%$ of the County's acreage. Walter $\mathrm{H}$. Johnson, Agriculture as a Compelitor for Land, in Economic Competiton for Land: Shasta County 48 (Univ. of Cal., Agric. Extension Serv. 1966).

40. A specialist in brokering private grazing leases stated that most of his landownerlessee relationships had endured for decades. Interview with Jim Cochran, Wm. Beatty \& Assocs., in Redding, Ca. (July 21, 1982). 
ten years, ${ }^{41}$ and they also tend to be automatically renewable. ${ }^{42}$ A cattleman who has been leasing a tract of forest for summer range thus tends to regard the leased tract as a normal part of his operations. Although the forest areas remain green in summer, they contain too few open meadows to support many cattle. Traditionalists may have to lease 300 acres of forest per animal unit: Thus, a traditionalist with a herd of only 100 animals may lease during the summer a forest equal in area to the city of San Francisco.

The fencing of these far flung forest leaseholds has never been cost-justified in the eyes of either the timber owners or their traditionalist lessees. To reduce the risk of livestock trespassing on contiguous lands, forest leasehold boundaries are often drawn to follow natural barriers such as ridges and gulches. But adroit boundary drawing is hardly a foolproof method for controlling strays. Mountain cattle tend to drift down the drainage areas to lower elevations, especially when the weather turns cold or a drought dries the upland creeks. Lessees occasionally erect drift fences across mountain valleys to block the most obvious migration routes. Because drift fences are easily destroyed by winter snows, however, traditionalists often let their animals roam at will in the mountains. Even a forest lessee who has ridden his leasehold periodically during the summer risks being unable to find part of his herd when he gathers his livestock in midOctober. After the October gathering, a traditionalist returns his animals to a base ranch at a lower elevation, and feeds them hay or other stored feed for a few months until the winter rains revive the natural grasses on the base ranch pastures. ${ }^{43}$

\section{The modernists.}

Modernists among the Shasta County cattlemen keep their livestock behind fences at all times in order to increase their control over their herds. ${ }^{44}$ To satisfy the need for summer forage that originally caused traditionalist cattlemen to enter into forest leases, modernists install ditches and sprinklers to irrigate base

41. See 43 U.S.C.A. $\$ \S 315$ b, 1752 (Supp. 1983).

42. Interviews with Terry Brumley of the U.S.F.S., in Redding, Ca. (Aug. 9, 1982), and Paul McClain of the B.L.M., in Redding, Ca. (July 9, 1982).

43. Untimely grazing may damage rangeland. If grazing occurs too early, it may kill immature grass; if it occurs too late, the livestock may eat seeds needed for the following year's forage. Grazing leases therefore regulate entry and exit dates.

44. See notes 47-50 infra and accompanying text. 
ranch pastures. One acre of irrigated pasture can support a cow and calf for an entire summer. A modernist who can irrigate about ten percent of his lands is usually able to run a year-round, fenced operation. ${ }^{45}$

Modernists are more active than traditionalists in managing ranchland vegetation. If not controlled, the native brush that thrives in the foothill zone would consume much of the scarce ground water and soil nutrients that competing grasses need. Modernist foothill ranchers fight the brush by setting controlled burns, spreading herbicides, and dragging chains from tractors to uproot the larger plants.46 Using these clearing techniques, leading modernist cattlemen have transformed unproductive foothill areas into valuable pasturelands.

Modernists tend to be younger than traditionalists, have more formal education, and be more active in the Cattlemen's Association. Some modernists view the traditionalists as old-fashioned and primitive. Traditionalists, however, see themselves as the "real" cattlemen-the ones who can recognize a cow at half a mile and sleep out under the stars in the tradition of the nineteenth century cowboy.

Despite their stylistic differences, modernists and traditionalists have much in common. Members of both groups believe that the life of the cattleman is the best possible in western America. They enjoy riding horses and regularly wearing blue jeans, cowboy hats, and cowboy boots. They regard the late John Wayne as their kind of guy. Although traditionalists have a much greater stake than modernists do in keeping the Board of Supervisors from closing the range, modernist cattlemen typically join the traditionalists in opposing proposed legal changes that would increase the liabilities of owners of stray cattle.

45. A cattleman needs at least ten acres of unirrigated land per AUM for winter range. If he were to irrigate ten percent of this acreage, he would have enough irrigated pasture for summer range. Instead of irrigating, a modernist who prefers operating behind fences may move his herds to fenced summer grasslands located in the high mountain valleys of Superior California. ("Superior California" is a regionally popular geographical designation that, unlike "Northern California," distinguishes the northmost counties from the Bay Area.)

46. See generally H. Heady, supra note 38 , at 253-55, 258, 280-329. On controlled burns, see also CaL. Pub. Res. Code \$§ 4475-94 (West Supp. 1981) (delineating the role of the State Department of Forestry); L. Stoddart \& A. Smith, Range Management 383-94 (1943) (describing the effects of burning upon various types of rangeland). 


\section{The Benefits and Costs of Boundary Fences}

The study of cattle trespass incidents is inevitably a study of fencing. A fence demarcates boundaries, keeps out human and animal trespassers, and keeps in the fencebuilder's own animals. In the Farmer-Rancher Parable, Coase perceived the sole benefit of a fence to be the reduction of trespass damages to crops. ${ }^{47}$ In fact, cattlemen enclose their lands largely to prevent damage to their own livestock. Predators, rustlers, winter snows, and poisonous plants such as larkspur all pose potentially lethal threats to cattle roaming unfenced countryside. ${ }^{48}$ Cattlemen also worry that a wandering cow will be impregnated by a bull of worthless pedigree. Furthermore, fencing makes it easier for a rancher to provide salt and other useful diet supplements, and to prevent the weight loss likely to occur when cattle walk long distances.

The prices of grazing leases reflect the value that ranchers place on fences. In 1982, fenced land in the Northeastern Sector rented for about $\$ 10$ per animal unit month, whereas unfenced land rented for about $\$ 3.49$ Because both arrangements yield the same quantity of forage, the rent differential provides a rough measure of how much ranchers value the protection and control that boundary fences provide. ${ }^{50}$

Since 1874 , the year J.F. Glidden took out the first patent on barbed wire, the barbed wire fence has been the standard American technology for enclosing livestock. ${ }^{51}$ California's statutory

47. See Coase, supra note 1 , at 3,5 .

48. Rancher Dick Coombs, the epitome of honor in rural Shasta County, counseled that "[I]f you don't fence, your neighbors get your cattle, and their cattle get your feed."

During the nineteenth century, when cattlemen let their stock loose on the Great Plains during the winter, even the best managers were likely to lose five percent of their mature animals each grazing season. D. Boorstin, The Americans: The Democratic Experience 10 (1973). In the Northwest during the same time period, losses ran about $10 \%$. J. Ouiphant, On the Cattle Ranges of the Oregon Country 240-41 (1968). In Wyoming and Montana, during the disastrous winter of $1885-1886$, blizzards killed $85 \%$ or more of the livestock in some herds. E. Oscood, supra note 37, at 216-18.

49. These are rough averages of figures that ranchers and grazing-lease specialists offered in interviews. For the definition of "animal unit month," see note 38 supra.

50. The quality of forage of course varies from pasture to pasture, and is apt to be better where a landowner has deliberately tried to cultivate his grasses.

51. D. DARY, supra note 37, at 308-31, recounts the impact of the advent of barbed wire on ranching practices nationally. Before barbed wire, the fencing-in of cattle was generally not economical in California. R. Cleland, supra note 37, at 62.

A standard barbed wire fence will not contain sheep or hogs. To fence in those animals, Shasta County landowners use woven wire (which they variously refer to as "netting," "hogwire," or "field fence") for the bottom 39 or 47 inches of fence, and top it off with one to 
standard for a "lawful fence" was set at the turn of the century. It calls for three tightly stretched strands of barbed wire stapled to posts situated 16-1/2 feet (one rod) apart. ${ }^{52}$ Today, Shasta County ranchers tend to use at least four strands of barbed wire ${ }^{53}$ and they employ steel posts instead of the cedar posts customarily used earlier in the century. ${ }^{54}$

In 1982, the materials for a new four-strand, barbed wire fence in Shasta County cost about $\$ 2000$ per mile. Fence contractors charge at least as much for labor and overhead. ${ }^{55}$ Both

three strands of barbed wire. Because many ranchers in Shasta County owned sheep and swine a half century ago, many boundary fences there still contain woven wire.

Other types of boundary fences, such as electrified fence, are uncommon. However, an owner of horses may use board fencing, rather than barbed wire, to eliminate the risk that barbs pose to the coats of show animals. A natural barrier such as a gulch or a dense growth of brush may obviate the need for any type of boundary fencing. On fence technology, see generally U.S. DeP'T OF AGRiC., Farmers' Bull. No. 2247: Fences for The Farm ANd RuRal HOME (1971).

52. Cal. Agric. Code $§ 17121$ (West 1968). See also note 109 infra.

53. Because he believed his existing three-strand fence to be inadequate, rancher Dick Coombs persuaded his neighbor Ed Donaldson to join him in adding a fourth strand to their common boundary fence. Walt Johnson, the County Farm Advisor, recommends that barbed wire fences have five strands, and this is what $\mathrm{Al}$ Levy installed on the long stretch of new fence on the southern boundary of his mammoth ranch.

A rancher often erects "cross" or "division" fences to subdivide his own pastureland into separate fields. These fences enable a rancher to rest a pasture that would be damaged by further grazing, to control breeding, and to keep livestock away from a controlled burn.

Ranchers tend to invest less time and money in their cross fences than in their boundary fences, in part because a breach in a cross fence is less likely to result in the loss of an animal. Al Levy admitted to using only four strands for his cross fences and to not maintaining them quite as well as his five-strand boundary fences.

54. A half century ago, most Shasta County ranchers made their own fence posts by splitting logs. Should his own ranchland lack an adequate supply of logs, a rancher would contract with a private timber company to obtain the right to split downed cedar trees in the mountain forests.

Today farm supply stores offer ready made steel and wooden posts. Ranchers typically prefer the steel posts because they are less expensive, easier to drive into rocky soil, and more likely to survive a controlled burn. Wooden posts are still essential at corners, gates, stretch panels, and other places where extra strength is needed.

55. Interview with Carl Yokum of Northwest Fence, in Palo Cedro, Cal. (Aug. 11, 1982).

Technological advances-particularly the invention of barbed wire-have made fencing much less expensive relative to land and labor than it was in Abraham Lincoln's log-splitting days. Today, a newcomer to rural Shasta County would spend in the neighborhood of $\$ 40,000$ to purchase a 40 -acre ranchette, but for one-tenth of that sum he could hire a contractor to fence it with barbed wire. In the 1850 s, "[i]t was certainly a rare farm-maker who had not to invest more capital-or its equivalent in labor in the case of forested areas-in his fence than in land." Danhof, Farm-Mlaking Costs and the "Safety l'alve": 1850-60, $49 \mathrm{~J}$. PoL. ECON. 317, 345 (1941). Fencing costs in California during the 1850s are estimated to have been $\$ 300$ to $\$ 600$ per mile in the currency of the time. Id. at 345 n.78. See also Meade v. Watson, 67 Cal. 591, 595, 8 P. 311,313 (1885) (complaint asserted "value" of a stone boundary fence to be $\$ 1.75$ per rod or $\$ 560$ per mile). In the latter part of the nineteenth century, 
ranchers and ranchette owners customarily build their own fences and thereby drastically reduce out-of-pocket labor expenditures. ${ }^{56}$

Barbed wire fences require periodic maintenance, especially in Shasta County, where many natural forces conspire against fence wire. The extreme summer heat loosens the wire while the winter cold pulls it taut. The deer that migrate through the foothills during the wet season are generally able to jump cattle fences; but when a jumping deer fails to clear a fence cleanly, its hoof may break a tightly stretched top wire. ${ }^{57}$ Heavy winter rains, rotting posts, downed trees, unruly bulls, or wayward automobiles may also create a breach. A rancher or his hand therefore must spend a few days each spring, either on horseback or in a pickup truck, riding fence. A conscientious rancher also inspects his fences in the fall after the deer season, in part to see what damage trespassing hunters may have inflicted.58 With emergency repairs needed frequently, fence maintenance chores weigh constantly on a rancher's mind. ${ }^{59}$

Ranchers believe that the many benefits of perimeter barriers outweigh fence construction and maintenance costs. Cattlemen with permanent ranches in either the grasslands or foothills almost invariably have perimeter fences, as well as cross fences to divide their spreads into separate pastures. A ranchette owner, however, is unlikely to fence the boundary of his land unless he

mean family income in the United States was on the order of $\$ 600-\$ 800$ per year. See BurEAU of the Census, U.S. Dep'T of Commerce, 1 Historical Statistics of the United States: Colonial TIMEs to 1970322 (1975). Before the arrival of barbed wire, a mile of fence thus cost about as much as an average family's annual income. In 1981, the mean family income in the United States was $\$ 24,000$. See Bureau of the Census, U.S. Dep't of Commerce, Statistical Abstract of the United States 1982-1983, at 435 (1982). That income would have then been sufficient to purchase the installation of at least five miles of barbed wire fence in Shasta County.

56. I found only one rancher, and no ranchette owner, who admitted having contracted out fencing work. The fence contractors of Shasta County agreed that the vast majority of rural fencing is done on a do-it-yourself basis. Walt Johnson, the astute Farm Advisor for Shasta County, could not identify the name of a single fence contractor.

57. To qualify as "lawful," a barbed wire fence in California must have its top strand at least 48 inches above the ground. CAL. Agric. Code $\S 17121$ (West 1968). Farm experts recommend that the top wire of a five-strand fence be elevated 52 inches. See Fences for the FARM AND RuRal Home, supra note 51, at 17. The risk of damage from jumping deer has induced some fence contractors to warn against placing the top strand too high.

58. Veteran rancher and ex-Supervisor Norman Wagoner estimated that a cattleman working alone can inspect and repair a fence at a rate of about two miles per day.

59. Rancher Owen Shellworth estimated that he spent $25 \%$ of his work hours on fences, including corral fences. 
has livestock. In forest pastures, one observes either no fencing or only an occasional drift fence. ${ }^{60}$

Traditionalists running herds in unfenced mountain forests have provoked most of the closed-range political movements in Shasta County. ${ }^{61}$ During the summer months mountain cattle sometimes wander onto rural highways and ravage hay fields and gardens in the settled parts of the foothills. The recent proliferation of ranchettes in the foothills has aggravated these two risks and heightened opposition to the practice of running cattle at large.

\section{The Politics of Cattle Trespass in THE NORTHEASTERN FOOTHILLS}

Loose cattle often cause political flaps in Shasta County. Many rural residents know that the Board of Supervisors has the power to adopt closed-range ordinances. They believe that these ordinances increase the civil liabilities of owners of stray livestock not only for trespass damages, but also, and more significantly, for damages stemming from highway collisions between vehicles and domestic animals. When residents and motorists in a particular area of the county suffer a rash of cattle-related incidents, they are likely to report their grievances to their local supervisor, whom they ask to mediate the conflict or to support a closedrange ordinance designed to cure the problem. A closure reduces the number of loose cattle because fear of liability to motorists makes traditionalists reluctant to run cattle at large in closed range. ${ }^{62}$

At least since 1970, the Board of Supervisors has required constituents who propose adoption of a closed-range ordinance to follow a special procedure. The complainants must draw up a petition that identifies a specific territory for closure, gather signatures on copies of the petition, and forward the signed petition to the Board. Although the Board does not insist upon the sub-

60. I did not learn of a single instance in which a forest owner, or a traditionalist cattleman who leased a forest for summer range, had fenced a forest boundary.

61. But they have not provoked all of them. Farm Advisor Walt Johnson could recall scveral instances in which the trigger had been a rancher, ostensibly operating behind fence, who had deliberately turned out his animals onto neighboring lands.

62. Rural residents in fact exaggerate the impact of a closed-range ordinance on the legal allocation of losses arising out of vehicle-livestock collisions. I do not discuss the highway collision chapter of the Shasta County story in this article, but will treat it at length in my forthcoming book. 
mission of a particular minimum number of signatures, closure proponents gather as many as possible. Upon receiving a petition, the Board's staff drafts an ordinance that will implement the closure and publicizes a hearing on the proposed measure. ${ }^{63}$ In practice, opponents usually receive sufficient notice of an upcoming hearing to gather signatures on a counterpetition. ${ }^{64}$ At the public hearing, the Board hears statements from proponents and opponents and then votes on the measure. The cattlemen have been quite successful in defeating proposed closures. Between 1946 and 1972, the Board approved sixteen closures in various parts of Shasta County, but most of those ordinances only involved lands on Redding's urban fringe. ${ }^{65}$

Prior to the 1973 Caton's Folly ordinance that closed an area near Round Mountain, the Board of Supervisors approved only one closure that affected a significant amount of rural territory east of the Sacramento River. In the early 1960s, mountain cattle began to appear in number along a stretch of State Highway 44 in the Shingletown-Viola area, thirty miles east of Redding. Highway 44 is the major route between Redding and Mount Lassen National Park. In 1965, the Board voted to close the range in a three-mile-wide strip of land straddling the highway for a distance of $121 / 2$ miles. ${ }^{66}$ This closure affected an area topographically similar to, but south of, the Northeastern Foothills. The Northeastern Foothills remained open range until the Caton's Folly ordinance. The history of that ordinance and of the Board's rejection of the Oak Run closure petition in 1982 helps reveal the role of elected local officials in cattle trespass disputes.

\section{A. Caton's Folly: The Closing of the Range at Round Mountain}

The hamlet of Round Mountain lies thirty miles northeast of Redding. Scattered along State Highway 299, the hamlet's main thoroughfare, are a general store, an elementary school, and a substation in Pacific Gas \& Electric's hydroelectric power grid. ${ }^{67}$

63. In the early 1980s, the Board held hearings on closed-range petitions no more often than twice a year, on dates in February and July.

64. In 1982, it was the Board's standard practice, upon receiving a closed-range petition, to notify the Shasta County Cattlemen's Association by mail.

65. The county's Department of Public Works periodically prepares and sells to the public a map listing all closed-range ordinances and showing the territories they affect. The statement in the text is based on this map.

66. Shasta County, Cal., Ordinance 459 (Aug. 8, 1966).

67. In March 1984, Round Mountain enjoyed a rare moment of national media attention 
The hamlet is 2000 feet in elevation, and is surrounded by higher foothills, the most prominent of which has given the hamlet its name. During the 1960 s, the area around Round Mountain, like the rest of the Northeastern Foothills, became increasingly dotted with ranchettes. The frustration of these ranchette owners over the perceived misdeeds of three traditionalists, Paul Totten, Bob Moquet, and Ward Kearney, helped spawn the Caton's Folly ordinance of 1973. The particular activities of these three deserve brief description.

In the early $1970 \mathrm{~s}$, Totten, a small-scale traditionalist with a base ranch west of Redding, leased some thirty square miles of Roseburg Lumber Company forest lands for summer range. ${ }^{68}$ The western boundary of Totten's leasehold was three miles east of the hamlet of Round Mountain and at a higher elevation. Just west of the boundary was an aging foothill farm with a sixty-acre irrigated field. John Woodbury had acquired this farm in 1966 and over a period of years had converted the irrigated field from natural grass to alfalfa. During the early 1970 s, Totten's mountain cattle found and repeatedly used a path that led from the meager offerings of the Roseburg forest to the banquet of Woodbury's unfenced alfalfa field. On occasions when Woodbury would telephone him to complain, Totten would eventually drive the cattle back up into the forest, but neither as promptly nor as irreversibly as Woodbury would have liked.

Bob Moquet's cattle were a more pervasive and longstanding nuisance. A tough and independent leader of a pioneer clan long settled in the Round Mountain area, Moquet aroused particular hostility because he was blatantly unresponsive to his neighbors' complaints. He believed that a cattleman had a divine right to let his cattle loose in the mountains during the summer. Steve Mattingly, a Modernist cattleman who raised registered Galloway cattle on a fenced ranch on Buzzard Roost Road, became particularly concerned that Moquet's hybrid bulls might impregnate his cows.

In the early 1970s, Dr. Arthur Cooley, a Redding physician, obtained a summer grazing lease on a large tract of National For-

when a circuit breaker malfunction in the PG\&E substation blacked out parts of six Western states. $S e \varepsilon$ San Francisco Chron., Mar. 1, 1984, at 1, col. 4.

68. The lessor in the early 1970s was actually the Kimberly-Clark Corporation. Kimberly-Clark sold its forest lands in the northeastern sector to the Roseburg Lumber Company in 1979. See note 22 supra. For simplicity, the text treats Roseburg as the continuous owner of these lands. 
est Service land situated a few miles west of Round Mountain, on Backbone Ridge. To manage his mountain herd of several hundred animals, Cooley hired Ward Kearney, a traditionalist cowboy of exceptional ability. Kearney shared Moquet's view that people who object to stray cattle should fence them out. Consequently, after driving Cooley's cattle to Backbone Ridge, Kearney would allow them to drift down into the ranchette areas and heavily traveled stretches of Highway 299 near Round Mountain.

Cooley, Moquet, and Totten's mountain cattle tipped the political balance in Round Mountain in favor of closure. In early 1973, Mattingly, Woodbury, and a few longtime area residents began meeting to discuss the problem of mountain cattle. These anti-traditionalists eventually drew up and gathered signatures on a petition that asked the Board of Supervisors to convert from open to closed range a seven by eight mile rectangle of territory centered on Round Mountain. It is not clear who drew the exact boundaries of this rectangle. Not surprisingly, all of the activists' lands fell within its perimeter. In the end, 72 persons, mostly Round Mountain residents, signed the closed-range petition.

On March 10, 1973, Mattingly mailed the signed petition to John Caton, the newly elected Board member for the supervisoral district that included the Northeastern Foothills. Caton lived on a ranchette in Montgomery Creek, a hamlet situated three miles northeast of Round Mountain on Highway 299. Caton shared many of the cattlemen's values, yet was aware that mountain cattle had been endangering both residents and motorists. The deepening conflict between traditionalist cattlemen and the residents of the Round Mountain area placed Caton in a delicate political position. He offered to help mediate and asked Mattingly and the other petitioners to wait a few months to see whether the problem would abate. It did not. During the summer of 1973, mountain cattle entered Woodbury's alfalfa field on over a dozen occasions. Woodbury said he telephoned Caton to complain on each occasion.

On December 3, 1973, the Board of Supervisors finally held its hearing on the anti-traditionalists' petition to close the fifty-six square-mile rectangle. The hearing was lightly attended. John Woodbury, pasture owner Phil Ritchie, and ranchette owner Ted Plomeson spoke in favor of the closure. The only significant speaker in opposition was Dr. Cooley, whose protestations of economic hardship elicited little sympathy. The official minutes 
of the Board's meeting contain no indication that a representative of the Shasta County Cattlemen's Association was present. At the end of the session, the Board voted by a margin of 4 to 1 , with Caton in the majority, to declare that the fifty-six squaremile rectangle outlined in the March petition had "ceased to be devoted chiefly to grazing"- -the legal language necessary to convert the area from open range to closed range. ${ }^{69}$

With the exception of a few modernists such as Mattingly, Shasta County cattlemen soon came to rue their failure to fight the Round Mountain closure. To chide Caton for supporting what they regarded as a lamentable precedent, they referred to the affected area as "Caton's Folly" or "Caton's Acres." Caton got the point. During the next decade, he successfully persuaded the Board to reject all petitions that would have closed additional territories in the Northeastern Foothills.

\section{B. Caton's Repentance: The Defeat of the Oak Run Closure Petition}

Caton's change of heart is best illustrated by his handling of a 1981 petition that asked the Board to close 96 square miles of range in the Oak Run area just southwest of Caton's Folly. The hamlet of Oak Run sits only three miles south of the southwestern corner of Caton's Folly. The hamlet's elevation is 1600 feet, a level where the grassy plains blend with the tangle of brush and trees that typify the foothills. During 1981-1982, only a few months before I conducted most of my interviews, the Oak Run area had been the site of perhaps the most heated closed-range battle in the history of Shasta County. Frank Ellis, a recent entrant into the bigtime cattle business, had singlehandedly provoked the circulation of a petition that sought to triple the area of closed range in the Northeastern Foothills.

\section{Frank Ellis.}

Ellis, accompanied by his wife and school-age children, first moved to Shasta County in about 1973. A rancher and real estate broker by profession, Ellis was then 58 years old. He immediately acquired a functioning 2500-acre ranch astride the Oak Run Road two miles west of Oak Run and just south of an area sprouting ranchettes. The size and prominent location of Ellis' base ranch helped to make him a conspicuous personality in the

69. Shasta County, Cal., Ordinance 498 (Dec. 3, 1973). 
Northeastern Foothills. Ellis (who declined my request for an interview) was by all reports a man capable of great charm. But, according to his neighbors, beneath this appealing surface lay a ruthless ambition for wealth and power. Many who dealt with Ellis came to regard him as capricious, spiteful, and not always good for his word. He became the target of numerous lawsuits, and for a time even had an attorney on retainer. One may think of him as the "J.R. Ewing of Shasta County" (although he lived in a style much less luxurious than that of his television counterpart). Although Ellis' aggressive and colorful personality won him a few admirers, his more honorable neighbors and rural acquaintances came to view Ellis as an untrustworthy bully.

During the late 1970s, Ellis built up the largest ranching empire in the Northeastern Foothills. First, he obtained a grazing lease on a section of BLM land to the west of his base ranch. Then in 1978, he persuaded the absentee owners of the largest ranching estate in the area to hire him to manage their scattered grasslands and foothills. By this one stroke, Ellis won control over another 20 square miles of pasture. Ellis eventually purchased hundreds of cattle on credit and hired a band of Mexican braceros to tend them.

The various components of Ellis' ranching empire were not physically connected. Ellis knew that all his holdings were within open range, but he erroneously interpreted this to mean that he could legally herd his livestock onto any land that was not fenced. When moving his livestock about, Ellis' cowboys not only deliberately crossed the unfenced private lands of others, but also used those lands as free pasture. ${ }^{70}$ By 1981, Ellis' drovers were aggressively running a herd of two to three thousand cattle at large in the grasslands and lower foothills northeast of Redding, an area where virtually all other cattlemen were Modernists who kept their animals behind fences.

\section{Ellis' antagonists.}

Most of the lands that Ellis' livestock invaded were uncultivated and uninhabited tracts held by speculators, who, if anything, appreciated a herd coming through to beat back the brush. Yet in some areas, particularly those near Oak Run itself, Ellis' trespass victims were ranchette owners who had recently moved

70. Although they occurred in open range, these entries were intentional and therefore tortious. See text accompanying notes 109-110 infra. 
to the Northeastern Foothills in search of a pastoral life. Ellis' marauding herds quickly became the bane of these ranchette owners. At least eight built fences at their own expense specifically to keep Ellis' animals off their lands. Although at least two of these ranchette owners saw Ellis as acting within his rights, most of them-in particular, Doug Heinz- did not.

Heinz, a skilled craftsman from southern California, moved to the Northeastern Foothills in 1978 with his wife and small children. The Heinzes acquired a house on a twenty-acre ranchette situated in open range west of Oak Run and about one mile from Ellis' base ranch. As a hobby, Heinz started to raise a few horses and cows on a twelve-acre portion of his ranchette that was enclosed by a five-strand barbed wire fence. The frequent passage of Ellis' herds punctured Heinz's dreams of small-scale squiredom.

According to Heinz, he and Ellis started off on polite terms. On three or four occasions in 1979, several of Ellis' cattle jumped over or broke through Heinz's fence. Heinz reacted to these early trespasses by telephoning Ellis. Ellis' response was to send his drovers to chase the cows within Heinz's field to tire them so they could then be coaxed through the fence. This method of retrieval battered Heinz's fences and Ellis' drovers never repaired the damage. Heinz's patience ran out one snowy day when he discovered that Ellis' hands had dropped hay for 200 cattle in the narrow snowplowed driveway leading to his ranchette. The milling herd that flocked to the hay included cows that had just calved, and these skittish new mothers frightened Heinz's small children.

Although most of Heinz's ranchette-owning neighbors had passively endured indignities from Ellis' livestock, Heinz was relatively short-tempered. He purchased a shotgun and called the county sheriff to protest Ellis' activities. According to what Ellis later told acquaintances, Heinz also began to threaten that Ellis might find "dead cattle." On the next occasion that Ellis' cattle broke through the fence, Heinz seized three animals and held them for three months without notifying Ellis. This incident eventually led to a lawsuit by Heinz to recover boarding costs and to a countersuit by Ellis for mistreatment of Ellis' animals. ${ }^{71}$

71. See Heinz v. Ellis, No. 81 SC 7 (Cent. Valley Just. Ct. filed Jan. 8, 1981); Ellis v. Heinz, No. 81 CV 6 (Cent. Valley Just. Ct. filed Jan. 16, 1981). (The names in these citations are pseudonyms). See also text accompanying notes 155-158 infra. 
In early 1981, while his lawsuit against Ellis was still pending, Heinz began a political crusade to stop Ellis' at-large grazing practices.

Heinz anticipated recruiting a host of allies, and not just among his fellow ranchette owners. During 1978-1981, virtually every foothill motorist had reason to be annoyed at Ellis' failure to keep his livestock off the foothill roads. When Ellis' stock were being moved along the highways, motorists were often delayed for up to an hour. On a half dozen occasions, vehicles collided with Ellis' stock on the Oak Run Road. Heinz succeeded in rallying to the anti-Ellis cause dozens of ranchette-owning newcomers, as well as members of at least one respected and longestablished ranching family in the Oak Run area.

\section{Caton's mediation and the battle of petitions.}

During 1981, Heinz and his allies peppered their local supervisor, John Gaton, with complaints about Ellis' herds. Since his christening at Round Mountain eight years earlier, Caton had become a veteran of political disputes over trespassing cattle. Caton knew that if he supported a closed-range ordinance for the Oak Run area, he would further alienate the powerful cattlemen's lobby, a group had never forgiven him for supporting the Caton's Folly ordinance. On the other hand, if Caton opposed the closure, he would offend a potentially more numerous, if less organized, group comprised of the ranchette owners and motorists that Ellis' herds endangered. Caton sought to defuse the controversy before a formal closure petition surfaced. Working in the spring of 1981 with County Animal Control Officer Brad Bogue, Caton threatened to support a closed-range ordinance for the Oak Run area if Ellis failed to build a fence along a three-mile stretch of the Oak Run Road that Ellis' herds made particularly dangerous. In response, Ellis promised Caton that he would build the fence. But as the summer of 1981 dragged on without any sign that Ellis would perform, Caton began to regard circulation of a closed-range petition as inevitable.

Caton's political instincts proved to be accurate. Some members of the anti-Ellis group preferred to postpone circulating a petition until they had exhausted other types of mediation; this faction, for example, wanted to ask the Shasta County Cattlemen's Association to request Ellis to manage his herds more responsibly. But Heinz decided to force the issue. In the fall of 
1981, without consulting some of his leading allies, he drafted and began to circulate a petition designed to close the range in a 96 square-mile area southwest of, and abutting, Caton's Folly. Heinz drew the boundaries broadly in an effort to cast the entire Ellis empire into closed range. The petition did not mention Ellis by name, but it did state that "Our reasons for this stem mostly from the inconsideration and abuse of the open range law of one rancher."72 Heinz and his allies gathered 42 signaturesan unimpressive total-and delivered their petition to John Caton in late November 1981.

The Board of Supervisors was scheduled to hold its next hearing on closure petitions three months later, in February 1982. The interval enabled Caton to minimize the political risks posed by the Heinz petition. He immediately publicized receipt of the petition, thereby helping the opposition to organize a countercampaign. Caton showed the Heinz petition to Wayne Thompson, a small-scale sheep rancher who lived on the Oak Run Road. Thompson enlisted his neighbor Larry Brennan, a college graduate who raised a few horses as a hobby on a large ranchette nearby, to draft a counterpetition urging the Board to keep the area open. ${ }^{73}$ Thompson tirelessly circulated the counterpetition in the Oak Run area. Prior to the February hearing, Thompson and his associates submitted to the Board the names of 146 persons, mostly residents of the Oak Run area, who had signed their counterpetition. Heinz's temperamental personality and lack of roots in the area limited his own success and aided Thompson's, who outsolicited him by a margin of more than three to one.

72. The petition continued:

Our reasons to list a few are:

1. Unsafe roadways due to poorly maintained fences, cows are continually on the roads and jepardizing [sic] the safety of school children.

2. Property destruction of the trespassing cows on private property.

3. Cutting of fences on private property to herd the cows with more ease to other areas of private property.

4. Interference of range cows with private herds.

73. The counterpetition began:

We feel that the "open range" system serves many purposes for the large and small rancher.

1. Limits of liability.

2. Fire protection-through grazing, keeping the grass down.

3. Biological control-through natural fertilization of soil of rangeland, timber production, fuel-wood production.

4. Natural predator control.

5. Prevention of soil erosion due to stronger root system with annual grasses. 
The Board also received a second counterpetition. Following standard procedures adopted after the Round Mountain controversy, the Board's staff had automatically informed the Shasta County Cattlemen's Association that the Board had received Heinz's closed-range petition. The Association's leaders then circulated a petition on their own. Their petition to keep the range open attracted only 24 signers, but many were members of well-known ranching families operating northeast of Redding.

Caton's last major step after the Heinz petition surfaced was to remind Ellis that Caton's decision on the closure petition would rest largely on whether Ellis kept his promise to build the three miles of fence along Oak Run Road. Ellis finally responded-grudgingly. By the time of the Board's hearing on February 2, 1982, Ellis' employees had erected three miles of five-strand barbed wire fence, a project that may have cost Ellis as much as $\$ 10,000$. The fence was positioned on private lands (mostly owned by speculators) on which Ellis had grazed his herds without fee. The new fence helped to reassure motorists; it thus became a conspicuous monument to Caton's effectiveness. The fence offered no relief, however, to ranchette owners such as Heinz whose lands lay between Ellis' ranch and the new fence.

\section{The hearing and its aftermath.}

At the Board's hearing on February 2, 1982, Caton kept his part of his bargain with Ellis. Caton's decision to oppose the closure had become an easy one. Not only had Thompson's counterpetition attracted far more signatories than the Heinz petition had, but Thompson and the cattlemen were also more successful than the Heinz group in turning out supporters at the Board meeting. As ranchette owner and Heinz ally Jeff Marotta stated, "When I saw all those cowboy hats [in the hearing room] I knew we were going to lose." At the hearing, six speakers, including Doug Heinz, spoke in favor of the closure, but thirteen, including Bob Bosworth, president of the Shasta County Cattlemen's Association, spoke against it. Although the hall was packed, Ellis himself was not present. As someone said that night, "He wouldn't dare to be."74

Caton was also the beneficiary of a startling stroke of good

74. Just one speaker at the meeting, cattleman Marty Fancher, referred to Ellis by name. Even the members of the anti-Ellis group discreetly spoke only of "one rancher" whose misdeeds had provoked the petition. 
fortune: The Ellis ranching empire had just begun to crumble. Ellis had bought hundreds of cattle on credit in anticipation that beef prices would rise. Instead, prices had fallen. This setback, arriving on top of a variety of other financial reverses left Ellis without funds to pay creditors. A week or two before the Board's hearing, Ellis' banks had begun repossessing his cattle and the news immediately circulated within the gossip mills of the Northeastern Foothills.

When the testimony at the hearing came to a close, the other supervisors stated that they would defer to John Caton, the supervisor in whose district the proposed closure lay. Caton recommended that the area remain as open range but added that, if the problem were to continue, the Board should consider closing four sections of land where Heinz and most of the other complaining ranchette owners lived. The Board promptly voted unanimously to deny the Heinz petition. To smooth the waters, Dan Gover, the Board's chairman and a rancher himself, asked Bob Bosworth, president of the county Cattlemen's Association, to meet with Ellis, Heinz, and county animal control officials to see what could be done to control Ellis' herds. ${ }^{75}$ Caton had repented for Caton's Folly.

Within a few months of the hearing, both Heinz and Ellis were gone from the Northeastern Foothills. In 1980, Heinz had begun planning the construction of a house in Redding for his family. Only a few days after the Board rejected his petition, he moved out of the ranchette in Oak Run and into his newly completed Redding house. Ellis' stay in Oak Run lasted only three months longer than Heinz's. The banks seized Ellis' cattle, and his creditors were lining up with claims on his ranch. In May 1982, Ellis moved his family 100 miles south to a farm in another California county in the Central Valley. As his parting shot to Shasta County, Ellis ordered his hands to destroy the three miles of fence along the Oak Run Road that he had ordered built just six months before. On the day the Board held its hearing, the two leading players in the drama both knew that they were about to depart from the stage. ${ }^{76}$

75. The proposed meeting was never held, in part because the cattlemen were willing to use only informal sanctions, and, as Bosworth said at the hearing in response to a supervisor's question, this sort of pressure wouldn't work with Ellis because, "He hasn't been in [the County] all that long."

76. This datum is consistent with the widely accepted theoretical proposition that the lack of a prospective long-term future relationship makes disputants less likely to resolve their 


\section{RESEARCH METHODS}

I chose the Round Mountain-Oak Run area as the focus for the microscopic study because it had witnessed both an actual and a threatened closure of the range. The area presented opportunities for both longitudinal and cross-sectional analyses. A longitudinal analysis would track the behavior of specific cattlemen and farmers over a span of years in the midst of which an applicable closed-range ordinance had been adopted. A crosssectional analysis would examine varied locations, rather than time periods, to determine whether on a particular date cattlemen and farmers behaved differently in open-range areas than in closed-range areas. I designed the field study to allow both types of inquiries. ${ }^{77}$

The 56 square-miles in Caton's Folly almost equals the size of Washington, D.C. I decided to concentrate the landowner interviews within the subarea that straddled Caton's Folly's southern boundary. This subarea provided opportunities for cross-sectional analysis because it contained both open-range and closedrange, including some open-range that had recently been subjected to an unsuccessful closure petition. ${ }^{78}$

My research techniques were more similar to those used in anthropology or in-depth journalism than to those used in econometrics or sociometrics. I relied primarily on interviews with two groups of people: (1) landowners in the study area, and

differences without the help of third parties, and hence more likely to resort to legal and political action. See text accompanying notes 139-141 infra.

77. An ideal research design makes use of time-series data for both experimental and control areas. See Lempert, Strategies of Research Design in the Legal Impact Study: The Control of Rival Hypotheses, 1 LAw \& Soc'y REv. 111, 130-32 (1966).

78. The area around the southern border of Caton's Folly offered several advantages. First, whereas the other three boundaries of Caton's Folly traversed lightly settled private forest, the southern border area was well-settled and thus more likely to be conflict-ridden. Second, only the southern area included some territory that had been threatened with a closure. Third, an investigator conducting a cross-sectional study into the impact of law should pick a situation where the legal boundaries are essentially random with regard to the social and topographic variables that may affect human conduct. Were the boundary not randomly drawn, any differences in landowner behavior that the investigator discovered between the areas might be the result of preexisting conditions (which perhaps caused the line to be drawn where it was), and not the result of differences in legal regimes. The southern boundary of Caton's Folly appeared to be a random line. None of the drafters of the Caton's Folly petition (the persons who selected this boundary) lived near it, and neither did any appreciable number of the petition's signatories. Moreover, the terrain the southern boundary crosses is highly varied, rising from foothills at an elevation of 2100 feet at the western end, to mountain forest at an elevation of 4400 feet at the eastern end. An eight-mile east-west line drawn straight across diverse terrain seems unlikely to have been the product of a gerrymander. 
(2) a larger number of "specialists" who were knowledgeable about how rural residents resolve stray cattle disputes. Instead of interviewing many persons who saw the problem from the same perspective, I sought out lesser numbers representing many different perspectives.

Of seventy-three total interviews (most of which were conducted during the summer of 1982), twenty-eight were with persons owning land in the rural area northeast of Redding. Eleven of these twenty-eight owned land inside Caton's Folly; ten owned land outside but within three miles of its southern border, mostly in areas that the Heinz closure petition would have affected; and three more-Hailey, McCall, and Shellworth-owned land both inside and outside Caton's Folly. Of the twenty-eight landowners, eleven could be described as cattle ranchers, four as farmers (whose chief agricultural activity was producing feed for livestock), and thirteen as ranchette owners (some of whom owned farm animals as a hobby). Twenty of the twenty-eight landowners were interviewed face-to-face. Seventeen of these interviews were in-depth sessions lasting one-and-a-half to two hours. The other eight landowner interviews were conducted by telephone; these telephone conversations averaged fifteen minutes in length.

The landowner interviews suffer from several shortcornings as a data source. First, 28 is a small sample. Second, I did not randomly select the people I interviewed; rather, I tended to seek out residents who had either owned cattle, been victims of trespass incidents, or been active in the political battles over closedrange petitions. I also made a particular effort to interview the owners of the largest farms and ranches in the study area. Compared to average foothill landowners, my informants were probably older, wealthier (although still of modest means), longer in residence in northeastern Shasta County, and more active in community affairs. Although most respondents talked without hesitation-indeed, usually with enthusiasm-cooperative people were undoubtedly somewhat overrepresented in the sample. Third, I decided not to use a standardized survey instrument, in part because a formal list of questions might have made respondents ill-at-ease. ${ }^{79}$ Fourth, some memories were undoubtedly

79. The authors of many leading microscopic law and society studies have used similar research methods. In his memorable study of contract law, Macaulay interviewed 68 businessmen and lawyers in Wisconsin, apparently without the aid of a standardized questionnaire. 
imperfect, and I had reason to suspect that a few landowners had deliberately recast history to place themselves in a better light. ${ }^{80}$

Rather than budget more time to landowner interviews, I chose to mitigate these shortcomings by using government records and interviews with certain specialists to cross-check what the landowners reported. Two types of government records-aerial photographs and court files-contained information relevant to cattle-trespass disputes. Federal agencies had taken aerial photographs of the western portion of Caton's Folly's southern border area in October 1973 and August 1980that is, two months before, and seven years after, the ordinance had been approved. ${ }^{81}$ Although these photos were taken at too high an altitude to indicate the presence of fences or individual animals, they reveal buildings and areas under cultivation. I obtained copies of these photographs in order to have evidence of actual changes in gross land use patterns in and near the study area during the relevant time period. ${ }^{82}$ I also searched the records of the state courts that serve the northeastern sector of Shasta County and noted lawsuits arising out of stray livestock incidents. ${ }^{83}$

The other important cross-checks on the landowner interviews were the $\mathbf{5 0}$ interviews that I conducted with "specialists,"

See Macaulay, supra note 12, at 55-56. Ross's interviews with his 67 insurance adjusters were also unstructured. H. Ross, supra note 12 , at 10 . Llewellyn \& Hoebel's study of the Cheyenne was based on what sociologists call "memory cases"--tribal legends and tales related by interpreters. K. Llewellyn \& E. Hoebel, The Cheyenne Way viii-ix (1941). See also Palay, Comparative Institutional Economics: The Governance of Rail Freight Contracting, $13 \mathrm{~J}$. LEGal STud. 265, 271 (1984) (study based on 35 field interviews was conducted without the use of a formal questionnaire, in order to encourage the interviewees to be open in their responses).

On methods of what I call "microscopic" field research, see generally Blanck \& Turner, Gestalt Research: Clinical-Field-Research Approaches to Studying Organizations, in HANDBOOK OF ORGanizational Behavior 109-25 (J. Lorsch ed. 1986).

80. Because $I$ had concentrated my landowner interviews in a subarea, I often heard several interpretations of the same event; I was therefore better able to make an assessment of the credibility of different sources.

81. In October 1973, the Caton's Folly ordinance was pending and landowners might have anticipated its adoption. Thus, aerial photographs taken on an earlier date, had they been available, would have provided better evidence of the ex ante situation.

82. I hired a geobotanist skilled in remote sensing to analyze the two sets of aerial photographs. He detected no cross-sectional or longitudinal variations in land use patterns that would cast doubt on the findings presented in Part IV.

83. None of the relevant state courts index their cases by subject matter. To overcome this obstacle, I asked the judges and court clerks if they could recall stray cattle cases, looked for names of likely litigants in the plaintiff and defendant name indexes, and, in the Justice Courts, reviewed all complaints that had been filed during recent eleven-month periods. See also note 152 infra. 
namely, industry and government officials likely to interact with the subjects of the study. ${ }^{84}$ Eighty percent of the specialist interviews were conducted in person and the balance were conducted by telephone. The face-to-face sessions averaged 40 minutes in length. As in the landowner interviews, I took detailed handwritten notes during the sessions. ${ }^{85}$

\section{The Resolution of Animal Trespass Disputes in Shasta County}

This Part reports the frequency of cattle trespass incidents in Shasta County, presents relevant California trespass law, and recounts how Shasta County neighbors actually resolve their trespass disputes. In the Coasean Parable of the Farmer and the Rancher, the two neighbors both know and honor applicable legal rules. Much of law and economic scholarship has similarly assumed that law is efficacious in this way. ${ }^{86}$ This Part suggests that the assumption of efficacious law is more heroic than certain scholars have realized.

\section{A. Animal Trespass Incidents}

Every landowner interviewed, including all thirteen ranchette owners, reported at least one instance in which his lands had been invaded by someone else's livestock. Hay farmers grow what cattle especially like to eat, and thus expect frequent trespasses. ${ }^{87}$ Owners of large ranches are also common victims be-

84. The specialists interviewed were: the four state court judges most likely to have been involved in livestock-related cases arising in Shasta County's northeastern sector; six Redding attorneys who had rural landowners as clients; five members of the Board of Directors of the Shasta County Cattlemen's Association; eight adjusters and salesmen employed by the insurance companies that underwrite most of the livestock risks in eastern Shasta County; three real estate appraisers and assessors; eleven county officials (including the Brand Inspector, the Animal Control Officer, the Farm Advisor, a former District Attorney, and several supervisors, including John Caton); four fence contractors and fence material suppliers; six agents of forest owners that lease their lands for grazing; and three grazing lessees. Because several interviewees qualified both as specialists and as landowners, the total number of interviews was 73 , not 78 .

85. To avoid developing a reputation for undue nosiness, I never asked the landowners about either their religious convictions or their financial situations. Those variables might conceivably affect one's method of resolving low-level disputes; however, the interviewees never volunteered that religion or financial plight affected people's behavior.

86. See, e.g., Calabresi \& Melamed, supra note 7, at 1090-91 (assuming that the "state" is the sole source of entitlements).

87. John Woodbury suffered almost weekly incursions into his alfalfa field in 1973. See text following note 68 supra. Although the situation improved when many of the mountain 
cause they cannot keep their many miles of aging perimeter fence cattle-tight. Thus, when a rancher gathers his animals on his fenced pastures each spring, he is not startled to find a few head carrying a neighbor's brand.

Because cattle eat almost incessantly, a trespass victim's vegetation is always at risk. 88 Nevertheless, a victim usually regards the loss of grass as trivial so long as the owner removes the animals with reasonable promptness-that is, within a day or two if the animals are easy to corral. Trespassing livestock occasionally do cause more than nominal damage. Several ranchette owners reported incidents in which wayward cattle had damaged their fences and vegetable gardens; one farmer told of the ravaging of some of his ornamental trees.

The most serious trespasses reported were ones involving either at-large cattle or bulls. A ranchette owner narrated how mountain cattle had once invaded his house construction site, broken the windows, and contaminated the creek. A part-time horsebreeder told of buying seven tons of hay and stacking it on an unfenced portion of his fifty-acre ranchette, where it was then eaten by cattle that Frank Ellis had let roam free.

Rural residents especially fear trespasses by bulls. In a modern beef cattle herd, roughly one animal in twenty-five is a bull, whose principal function is to impregnate cows during their brief periods in heat. ${ }^{89}$ Bulls are twice as heavy as the other herd animals, ${ }^{90}$ and tend to be much more ornery. Several respondents had vivid memories of bull trespasses. A farmer who owned irrigated pasture was amazed at the depth of the hoof marks that an entering bull had made. A ranchette owner and a rancher told of barely escaping goring while attempting to corral invading

lessees subsequently declined to renew their leases, Woodbury was still experiencing a couple of cattle trespasses a year in the early 1980s. Another hay farmer, Phil Ritchie, identified six neighbors whose cattle had trespassed on his lands in recent years.

88. Beef cattle eat feed equal to about $2-1 / 2 \%$ of their body weight each day. Drvision of Agric. Sci., Univ. of Cal., Leaflet No. 21184, Beef Production in California 12-13 (Nov. 1980).

89. Cf. CAL. Agric. Code $\S 16803$ (West 1968) (cattlemen grazing herds on open-range must include at least one bull for every $30 \mathrm{cows}$ ). The refinement of artificial insemination techniques has enabled some ranchers to reduce the fraction of bulls in herds kept behind fences.

90. A Hereford bull has a mature weight of 2000 pounds, compared to 1100-1200 pounds for a mature Hereford cow. Steers (castrated male cattle) are typically slaughtered when they weigh between 1000 and 1150 pounds. BeEf Production in Californis, supra note 88 , at 3,5 . 
bulls. $^{91}$ Because an alien bull often enters in pursuit of cows in heat, owners of female animals fear illicit couplings that might produce offspring of an undesired pedigree. Although no cow owner reported actual damages from misbreeding, several mentioned that this risk especially worried them.

\section{B. Animal Trespass Law}

One of the most venerable English common law rules of strict liability in tort is the rule that an owner of domestic livestock is liable, even in the absence of negligence, for property damage that his animals cause while trespassing. ${ }^{92}$ This traditional English rule also applies in the closed-range areas of Shasta County. ${ }^{93}$

91. I learned of no cattle trespasses that had resulted in personal injury. Two insurance adjusters who frequently had been called upon to settle dog-bite claims could remember, between them, only one personal-injury claim arising from cattle-an instance in which a cow had stepped on someone's foot.

92. The case that has most commonly occurred, and which is most frequently to be found in the books, is as to the obligation of the owner of cattle which he has brought on his land, to prevent their escaping and doing mischief. The law as to them seems to be perfectly settled from early times; the owner must keep them in at his peril, or he will be answerable for the natural consequences of their escape; that is with regard to tame beasts, for the grass they eat and trample upon, though not for any injury to the person of others, for our ancestors have settled that it is not the general nature of horses to kick, or bulls to gore; but if the owner knows that the beast has a vicious propensity to attack man, he will be answerable for that too.

Fletcher v. Rylands, 1 L.R.-Ex. 265, 280 (1866) (Blackburn, J.). See also 3 W. Blackstone, Commentaries *211 ("A man is answerable for not only his own trespass, but that of his cattle also").

The operation of this rule in Great Britain is discussed in G. WILLIAMs, LiabILITY FOR Anmals I27-99 (1939). See also Wigmore, Responsibility for Tortious Acts: Its History, 7 Harv. L. REv. 441, 450-52 (1894) (asserting, at 451 n.1, that thirteenth century cases applied a strict liability rule to cattle trespass incidents).

93. See, e.g., Montezuma Improvement Co. v. Simmerly, 181 Cal. 722, 724, 189 P. 100, 101 (1919).

Hornbook law provides a few defenses to, and other limitations on, an animal owner's strict liability for trespass damages. When a cattleman has driven cattle along a highway from which they have strayed and damaged plaintiff's adjoining fields, the plaintiff must prove that the cattleman had been negligent in the management of the herd. See Restatement (Second) OF TORTS $\$ 505$ (1977). There is authority that trespasses caused by an act of God-for example, an unprecedented windstorm causing a breach in a fence-are not actionable. See id. at $\$ 504(3)$ (c). The Restatement also declines to impose liability for unforeseeable damage. Id. at $\$ 504(3)$ (a); see also Williams v. Goodwin, 41 Cal. App. 3d 496, 507, 116 Cal. Rptr. 200, 208 (1974) (recovery granted because personal injury caused by trespassing bull was within the scope of foreseeable harm).

A trespass victim's own misconduct, such as failing to close a cattle gate or breaching a contractual duty to build a fence, may also diminish or bar his recovery. See G. Williams, supra note 92, at 178-81; see also Restatement (SECOND) of TORTs § 504(4) (1977) (trespass 
In the open-range areas of the county-that is, in the great bulk of its rural territory-the English rule has been rejected in favor of the pro-cattleman "fencing out" rule that many grazing states adopted during the nineteenth century. ${ }^{94}$ In 1850 , just after California attained statehood, an open-range rule was adopted for the entire state. In that year, the legislature enacted a statute that entitled a victim of animal trespass to recover damages only when the victim had protected his lands with a "lawful fence."95 This pro-cattleman policy grew increasingly controver-

victim who fails to erect and maintain a fence required by common law or statute is barred from recovery). In California, misconduct by a plaintiff does not typically operate as a complete defense in a strict liability action. See Daly v. General Motors Corp., 20 Cal. 3d 725, 575 P.2d 1162, 144 Cal. Rptr. 380 (1978).

94. Many authorities assert that the Western states have been the chief followers of "fencing-out" rules. See, e.g., 2 F. Harper \& F. James, The Law of Torts $\$ 14.10$ (1956); W. Prosser, J. Wade, \& V. Schwartz, Cases and Materials on Torts 706-07 (7th ed. 1982). Nineteenth century treatises on fence law reveal, however, that in that era, "fencing out" was the dominant rule in the United States, particularly in the Northern states. See W. Thornton, The Law of Railroad Fences and Private Crossings \$§ 8-10 (1892) (identifying 13 states as following the English rule and 21 states as having fencing-out regimes); R. TYLER, THE LAW OF BOUNDARIES, FENCES, AND WINDOW LIGHTS 361-512 (1874) (state-by-state review of fence law, indicating, at 451 , that Michigan, for example, enacted a fencing-out statute in 1847); see also W. Cronon, Changes in the Land: Indians, Colonists, and the Ecology of New England 134-35 (1983) (the Plymouth and Massachusetts Bay colonies in Massachusetts required planters of corn to fence out livestock).

95. 1850 Cal. Stat., ch. 49, 131. See Comerford v. Dupuy, 17 Cal. 308 (1861) (judgment for defendant cattle owners where plaintiff's fence failed to meet lawful fence requirements of 1855 statute); Waters v. Moss, 12 Cal. 535 (1859) (dictum).

In California during that era, the open-range rule was probably more efficient than the English rule. Where there are many cultivated lands, as in England, a livestock owner is typically the cheapest cost avoider in animal-crop interactions because he can best control the whereabouts of his beasts. See Calabresi \& Hirschoff, Toward a Test for Sirict Liability in Torts, 81 YALE L.J. 1055, 1060 (1972) (risks should be assigned to the party best able to perform a costbenefit analysis of accident costs and accident prevention costs and to act on that analysis once it is made). There was little farming in California in the mid-nineteenth century, however, and the grazing of cattle was widespread. See generally R. Clezand, The Cattle on a Thousand Hills (2d ed. 1951) (despite the impact of the Gold Rush in northern California, southern California remained a typical cattle frontier for nearly 20 years thereafter). Consequently, it was cheaper to install fencing around the rare field crops than around the ubiquitous grazing areas. Cattlemen running animals at large would have incurred high transaction costs in organizing to erect fences that would reduce their common risk of tort liability; in contrast, because a single farmer could decide on his own whether or not to fence, he would incur lower transaction costs. If efficiency-minded frontier lawmakers assumed that actors knew and honored the legal rules, they therefore would have imposed the risk of trespass across an unfenced boundary on the farmer, the cheaper avoider of trespass damages to isolated fields of crops.

Lawful-fence statutes, still found in many western states, adopt an even more sophisticated approach to the allocation of animal trespass risks. The statutes identify specific fence technologies that farmers can employ to revive their rights to recover for trespass damages. See note 109 infra. When a trespass has occurred despite the presence of a lawful fence, the 
sial as California became more settled and field crops became more common. During the latter part of the nineteenth century, the California legislature enacted a series of statutes effectively closing the range in designated counties and thereby granting more protection to farmers who had not built fences. ${ }^{96}$

The closed-range exceptions began to swamp California's traditional open-range rule and eventually triggered a comprehensive legislative response. In the Estray Act of 1915,97 the legislature adopted for most of California the traditional English rule that the owner of livestock is strictly liable for trespass damage. ${ }^{98}$ This statute, however, retained the open-range rule for six counties in the lightly populated northern part of the state where the tradition of running cattle at large remained strong. The Estray Act of 1915 thus specifically excepted all of Shasta, Del Norte, Lassen, Modoc, Siskiyou, and Trinity Counties from the closed-range regime. ${ }^{99}$

statutes place the loss on the cattleman, the person who is usually the cheaper avoider of this sort of trespass, because he can best discover whether any of his animals are prone to break through or jump over fences and can best act on that knowledge.

Because lawful-fence rules provide rather bright-line standards, compared to negligence rules, they are relatively easy to communicate and apply. Lawful-fence statutes are thus suited to enforcement by lay "fence viewers"-private individuals whom some states have authorized to judge the quality of fencing and to assess trespass damages or fence construction costs. See note 111 infra.

96. See 3 CaL. JuR. 3D Animals $\S 55$, at 676 n.42 (1973) (citing 14 county-specific fencing statutes that the California legislature enacted between 1863 and 1878 and repealed in the 1930s); Note, Torts: Trespass by Animals upon Unenclosed Lands in California, 7 CaLIF. L. REv. 365 (1919).

97. 1915 Cal. Stat. 636 (current version at CAL. Agric. CoDE $§ \S 17,001-17,128$ (West 1968)).

98. Although the 1915 statute nominally dealt only with a trespass victim's rights to take up estrays, California case law has consistently held that a statutory right to seize estrays in the absence of a lawful fence carries with it the right to recover trespass damages under the traditional common law rule of strict liability. See Montezuma Improvement Co. v. Simmerly, 181 Cal. 722, 189 P. 100 (1919); Hahn v. Garratt, 69 Cal. 146, 10 P. 329 (1886); Williams v. Goodwin, 41 Cal. App. 3d 496, 116 Cal. Rptr. 200 (1974) (dictum).

99. 1915 Cal. Stat. 636 (current version at CAL. AGric. Code $\S \S 17,123-17,126$ (West 1968)). Subsequent amendments deleted the exemptions applicable to all of Del Norte County, and parts of Shasta and Trinity Counties. See Cal. AGric. Code §§ 17,123-17,126 (West 1968).

The California code authorizes the board of supervisors of any county to declare by ordinance that part or all of the county is "devoted chiefly to grazing." See CAL. Agric. Code $\$ 17,124$ (West 1968). A declaration of this sort converts the designated area to an openrange regime-that is, it takes from trespass victims who lack lawful fences their preexisting entitlement to seize estrays and to recover trespass damages. See Williams v. Goodwin, 41 Cal. App. 3d 496, 503 n.8, 116 Cal. Rptr. 200, 205 n.8 (1974) (dictum); 39 Op. Cal. Att'y Gen. 75 (1962).

Responding in part to lobbying efforts by local cattlemen's associations, an increasing 
In 1945, the Legislature enacted two amendments that dealt exclusively with Shasta County, the least rural of the six exempt counties. The first stated that a prime agricultural area just south of Redding was "not . . . devoted chiefly to grazing"-a declaration that the legislature had decided to close the range in that small area of the county. ${ }^{100}$ The second amendment empowered the Board of Supervisors of Shasta County to adopt ordinances designating additional areas of the county as places no longer devoted chiefly to grazing. This legal designation would make cattlemen strictly liable for trespass damage occurring in those locations. ${ }^{101}$ For the next 29 years, Shasta was the only California county to possess this special authority. ${ }^{102}$ Today, Shasta County has a crazy-quilt of open- and closed-range areas unmatched by any other California county. ${ }^{103}$

The distinction between open-range and closed-range has formal legal significance in Shasta County trespass disputes. In closed-range, the English rule governs and an animal owner, with rare exceptions, ${ }^{104}$ is strictly liable for trespass damage to prop-

number of California's foothill counties have converted parts of their mountain forest to open range. See, e.g., Amador County, Cal., Ordinance 590 (Apr. 26, 1977); Calavaras County, Cal., Ordinance 179 (June 3, 1940) (opening range in entire county), repealed by Ordinance 411 (Nov. 7, 1967) (referendum measure); Calavaras County, Cal., Ordinance 779 (Dec. 29, 1975) (townsite of Sheep Ranch); El Dorado County, Cal., Code §§ 16,501-16,505 (adopted Feb. 3, 1976); Mariposa County, Cal., Ordinance 128 (May 7, 1945) (the first of several ordinances opening the range in the National Forest areas of the county); Placer County, Cal., Ordinance 2017-B (June 29, 1976).

100. 1945 Cal. Stat. 1538-39 (current version at CaL. Agric. Code $\S 17126$ (West 1968)).

101. 1945 Cal. Stat. 1539 (current version at CAL. Agric. Code $\$ 17,127$ (West 1968)).

102. The state legislature granted the board of supervisors of Trinity County, Shasta's neighbor to the west, similar authority in 1974. 1974 Cal. Stat. 409 (current version at CAL. AGRIC. CoDE $\$ 17,127$ (West Supp. 1985)). Any closed-range county that exercises its statutory power to open the range in a particular area undoubtedly also has the power to switch that same area back to a closed regime. At least one California county has flip-fopped in this way. See note 99 supra (describing legal events in Calaveras County).

A number of western states that generally adhere to an open-range regime also authorize substate entities to selectively "close" parts of their range. See, e.g., Ricca v. Bojorquez, 13 Ariz. App. 10, 473 P.2d 812 (1970) (Arizona procedure entitling landowners to close range by petition to the county board of supervisors unconstitutionally delegates power to private parties); Maguire v. Yanke, 99 Idaho 829, 590 P.2d 85 (1978) (describing Idaho procedure whereby landowners can petition to close range on a district by district basis); WASH. Rev. CODE ANN. $\$ 16.24 .010$ (1962) (option to close range granted to counties without townships).

103. A map issued by the Shasta County Department of Public Works in 1981 showed 28 separate areas the Board of Supervisors had closed by ordinance since 1945. Although most of the closed areas were located near Redding, there were areas of closed-range in the hinterland in every direction from the city.

104. See note 93 supra. 
erty. In open-range areas, by contrast, even a livestock owner ${ }^{105}$ who has negligently managed his animals is generally not liable ${ }^{106}$ for trespass damage to the lands ${ }^{107}$ of a neighbor.

Even in open range, however, there remain three important pockets of trespass liability. First, owners of goats, swine, and vicious dogs are subjected to the English rule throughout Shasta County. ${ }^{108}$ Second, when a cattleman's livestock have trespassed

105. Persons other than the animal's owner could conceivably be held liable for an animal's damage. Livestock owned by one person often permissively graze on the lands of another. For example, both grazing leases and agistment arrangements-contracts to feed and care for the livestock of another-are common in cattle country. The California courts, as expansive as any state's in imposing tort liability, would likely hold a grazing landlord liable were he negligently to abet trespasses by a lessee's livestock. $C f$. Uccello v. Laudenslayer, 44 Cal. App. 3d 504, 118 Cal. Rptr. 741 (1975) (residential landlord who knew of tenant's vicious dog and had the power to have it removed owed a duty of care to tenants' invitees and could be liable for negligence to dog-bite victim). But cf. Blake v. Dunn Farms, Inc., 274 Ind. 560, 413 N.E.2d 560 (1980) (landlord not liable for damages stemming from escape of tenant's horse that he knew little about). See also Restatement (SECOND) of TORTs \$ 504 comment d (1977) (only a "possessor" of livestock, not the owner of the land from whence the animals escaped, is strictly liable for trespass damages); Annot., 21 A.L.R.4th 123 (1983) (liability of nonowner of livestock in highway collision cases). Because of this risk, the agent for many timberland owners in Shasta County includes a "hold harmless" clause in his standard grazing lease to entitle the lessor to indemnification from the lessee.

106. Prosser asserts that a trespass victim who lacks a lawful fence required by statute can still prevail against a cattle owner who was "at fault." See W. Prosser, HaNdBooK of the Law of Torts 498 n.58 (4th ed. 1971); see also W. Prosser, J. WAde \& V. SchwarTz, supra note 94 , at 707 . This implies that a fencing-out statute only deprives trespass victims of the right to proceed on a theory of strict liability; it lets them proceed on a theory of negligence.

In California, the weight of legal authority does not support the Prosser view. Except when the defendant intended that his cattle trespass, a plaintiff's proof of the presence of a lawful fence has been regarded as a prerequisite for recovery in open range. See, e.g., Logan v. Gedney, 38 Cal. 579 (1869); Comerford v. Dupuy, 17 Cal. 308 (1861). See also Restatement (SECOND) OF TORTS § 504 comment k (1977); 2 F. HARPER \& F. JAMES, supra note 94, § 14.10, at 829. To use a phrase that seems almost quaint in the current era of comparative negligence, in open range a California landowner without a lawful fence essentially "assumes the risk" that neighbors will negligently handle their cattle.

107. Other rules may apply when the injury has been to person or chattels. In closedrange, a cattle owner is strictly liable for foreseeable personal injuries that his livestock cause. See Williams v. Goodwin, 41 Cal. App. 3d 496, 116 Cal. Rptr. 200 (1974) (owner of trespassing bull strictly liable for trampling of night watchman in closed-range); Annot., 88 A.L.R.2d 709 (1963). But of. RESTATEMENT (SECOND) OF TORTS $\$ 504$ (1977) (denying possessor of unfenced land in open-range recovery for personal injuries on a strict liability theory).

In both open- and closed-range, the owner of a trespassing animal would be strictly liable if that animal were to kill animals belonging to the owner of the premises invaded. See CaL. Civ. Code $\$ 3341$ (West 1970); cf. CAL. AGRIC. Code $\$ 31501$ (West 1968) (owner of trespassing dog is liable for twice the value of damages to livestock and poultry).

108. See Cal. Agric. Code. $\$ 17128$ (West 1968) (excepting owners of "goats, swine, or hogs" from benefits of open-range rule); Shasta County Ordinance Code $\$ 3306$ (declaring it "unlawful" to permit "any vicious dog or other dangerous animal" to run at large).

The California Agricultural Code provides that "[a] person in charge of any stallion, bull, 
through, or over, a "lawful fence" that entirely encloses the victim's premises, the cattleman remains strictly liable for trespass damages. (A California statute, unamended since 1915, defines the technological standard that a fence must meet to be "lawful." ${ }^{109}$ ) Third, common law decisions make a livestock owner in open range liable for trespass when he intentionally causes his animals to enter the unfenced lands of another. Thus when Frank Ellis actively herded his cattle across the lands of his neighbors, he was liable for trespass. According to some precedents, he would have been liable for trespass had he merely placed his cat-

boar, ram, or male goat shall not turn out or permit such animal to be turned out or to run at large." Cal. Agric. CoDE $\$ 16702$ (West 1968). This provision is not compatible with CAL. AGRIC. CODE $\$ 16803$ (West 1968) (requiring the presence of one purebred bull for every 30 cows run at large). Brad Bogue, Shasta County's Animal Control Officer, interprets the latter section as controlling the former.

109. Section 17122 of the Agricultural Code reads:

In any county or part of a county devoted chiefly to grazing and so declared pursuant to this article, a person shall not have the right to take up any estray animal found upon his premises, or upon premises to which he has the right of possession, nor shall he have a lien thereon, unless the premises are entirely enclosed with a good and substantial fence.

Cal. Agric. Code $\$ 17122$ (West 1968) (emphasis added). Judicial decisions construe this sort of provision as also denying a person without such a fence the right to recover damages for cattle trespass. See note 98 supra. See also CaL. Agric. Code $\S 17128$ (West 1968).

Section 17121 describes the quality of fencing necessary to meet this standard:

A lawful fence is any fence which is good, strong, substantial, and sufficient to prevent the ingress and egress of livestock. No wire fence is a good and substantial fence within the meaning of this article unless it has three tightly stretched barbed wires securely fastened to posts of reasonable strength, firmly set in the ground not more than one rod [16-1/2 feet] apart, one of which wires shall be at least four feet above the surface of the ground. Any kind of wire or other fence of height, strength and capacity equal to or greater than the wire fence herein described is a good and substantial fence within the meaning of this article . . . .

CAL. Agric. Code $\S 17121$ (West 1968).

This statutory definition of a lawful fence remains essentially unchanged since 1919. Compare with 1919 Cal. Stat. 1150 . The definition is technologically obsolete because, at least in Shasta County, cattlemen customarily use at least four strands of barbed wire in their boundary fences. See note $\mathbf{5 3}$ supra. A fence that fails the statutory standard for "lawfulness" may be deemed to have been negligently built, thereby exposing the fencebuilder to liability for damage caused by the fence. See Loveland v. Gardner, 79 Cal. 317, 21 P. 766 (1889) (plaintiff can recover for damage his horses suffered when they encountered defendant's negligently stretched barbed wire fence).

California's statutory definitions of lawful fences before the invention of barbed wire are described in R. TYLER, supra note 94, at 482-84 (some samples: stone walls 4-1/2 feet high; rail fences 5-1/2 feet high; a five-foot high hedge). W. ThorTon, supra note 94, at 201-23, provides a state-by-state review of statutory standards for the adequacy of fences in the late nineteenth century.

Other states' current statutory definitions of lawful fences vary from California's. See, e.g., Ariz. Rev. Stat. ANn. \$ 24-501 (1971); Nev. Rev. Stat. § 569.450(1) (1979); Wash. Rev. CODE ANN. $\$ 16.60 .010$ (1962). Many of their provisions seem equally antiquated. 
tle on his own lands in a way that would make it substantially certain that they would venture onto his neighbors' pastures. ${ }^{110}$

When the law of either open- or closed-range entitles a trespass victim to relief, the remedy is usually an award of compensatory damages. ${ }^{111}$ A plaintiff who has suffered from continuing wrongful trespasses may also be entitled to an injunction against future incursions. ${ }^{112}$ Moreover, California's Estray Act entitles a landowner whose premises have been wrongly invaded by cattle to seize them as security for a claim to recover boarding costs and other damages. A trespass victim who invokes this procedure must provide proper notice to the Director of Agriculture; if certain statutory requirements are met, the animals can be sold

110. State courts have rather uniformly imposed tort liability on any cattleman who has actively herded his livestock onto the lands of another, even when the victim's land was situated in open-range. In some states, a cattleman has been held liable only when he has deliberately transported animals across the boundary line. See, e.g., Garcia v. Sumrall, 58 Ariz. 526, 121 P.2d 640 (1942); Richards v. Sanderson, 39 Colo. 270, 89 P. 769 (1907). In other states, the entry of a cattleman's livestock has also been regarded as intentionally tortious when he has left them on a range from which it was substantially certain that they would enter the plaintiff's lands. See, e.g., Lazarus v. Phelps, 152 U.S. 81 (1894); Mower v. Olsen, 49 Utah 373, 164 P. 482 (1917). See generally Annot., 158 A.L.R. 375 (1945).

Two reported California decisions deal with the issue of intentional trespass by livestock owners; in both, applicable statutes prohibited the "herding" of livestock on the lands of others. The more recent decision, Cramer v. Jenkins, 82 Cal. App. 269, 255 P. 877 (1927), supports the proposition that leaving animals in a range from which they are substantially certain to trespass constitutes tortious misconduct. But of. Logan v. Gedney, 38 Cal. 579 (1869) (implying that active herding may be required). The California Supreme Court's current pro-plaintiff predilections would incline it to follow the Cramer approach.

111. Because evidence of damage to forage is fleeting, some states (although currently not California) authorize the appointment of disinterested residents of the area to serve as "fence viewers" to assess the amount of the damages. See, e.g., WASH. Rev. Code AnN. $\$ 16.60 .015$ (Supp. 1986) ("damages [shall be] assessed by three reliable, disinterested parties and practical farmers, within five days next after the trespass has been committed . . . ."). See generally 35 Am. Jur. 2d Fences $\$ \S 24-32$ (1967). The practice of delegating the valuation of damages to fence viewers was widespread in the nineteenth century and before. See R. TyLER, supra note 94, at 395, 399, $459 \& 476$ (describing statutes in New York, Maine, Wisconsin, and Kansas); W. Cronon, supra note 94, at 135 (colonial Massachusetts). At least one of the early California fence statutes provided for the appointment of fence viewers. See 1860 Cal. Stat. 142 (viewers' role is to assess the contributions that would be needed from the landowners on each side to build a sufficient partition fence).

Some early California statutes authorized cattle-trespass victims to recover double damages in certain situations. See, e.g., 1850 Cal. Stat. 131 (victim enclosed by lawful fence can recover double damages for defendant's second offense). The Estray Act of 1915 contained no double damages provisions, and no reported California decision has granted this remedy in a cattle-trespass case. But see NEv. REv. STAT. \$ 569.440(1) (1979) (entitling trespass victim situated behind a lawful fence to recover double damages for second offense if the animal owner had been negligent).

112. See Montezuma Improvement Co. v. Simmerly, 181 Cal. 722, 189 P. 100 (1919); Blevins v. Mullally, 22 Cal. App. 519, 135 P. 307 (1913). 
to satisfy the claim. ${ }^{113}$

The formal law provides trespass victims with only limited self-help remedies. A victim can use reasonable force to drive the animals off his land.114 In addition, a trespass victim willing to give the animals proper care can seize estrays and bill the costs of their care to their owner. But a victim is generally not entitled to kill or wound the offending animals. ${ }^{115}$ For example, a fruitgrower in Mendocino County (a closed-range county) was recently convicted for malicious maiming of animals when, without prior warning to the livestock owner, he shot and killed livestock trespassing in his unfenced orchard. ${ }^{116}$ We shall see that in this respect the formal law diverges from Shasta County mores. ${ }^{117}$

The distinction between open-range and closed-range has

113. See Cal. Agric. Code $\S \S 17041,17042,17091-95,17122$ (West 1968 \& Supp. 1985). The animal owner may contest the propriety of the victim's invocation of this self-help remedy. See Wigmore v. Buell, 122 Cal. 144, 54 P. 600 (1898) (construing Estray Act of 1878); Yraceburn v. Cape, 60 Cal. App. 374, 212 P. 938 (1923) (victim wrongly invoked power to seize animals). The distraint procedure also poses potentially thorny state action and due process issues. $C f$. Flagg Brothers, Inc. v. Brooks, 436 U.S. 149 (1978) (warehouseman's sale of entrusted goods).

The "right to distrain animals damage feasant" has deep roots in the English common law. See 3 W. Blackstone, Commentaries *211; G. Williams, supra note 92, at 7-123.

114. People v. Dunn, 39 Cal. App. 3d 418, 114 Cal. Rptr. 164 (1974) (dictum).

Shasta County trespass victims sometimes follow the time-honored self-help strategy of herding the intruding stock to a distant and inconvenient location. See text accompanying note 145 infra. On the issue of whether this represents a reasonable exercise of self-help, compare Gilson v. Fisk, 8 N.H. 404 (1836) (trespass victim who drove herd three miles away held liable in damages for death of eight sheep), with Wells v. State, 13 S.W. 889 (Tex. Ct. App. 1890) (victim of intentional trespass did not violate criminal statute when he drove cattle 3-4 miles afield).

115. See Crawford v. Crawford, 88 Ga. 234, 14 S.E. 609 (1891) (statute entitled owner of slain cattle to treble damages); Bruister v. Haney, 233 Miss. 527, 102 So. 2d 806 (1958) (trespass victim held liable in damages for intentionally poisoning entering cattle); Ford v. Taggart, 4 Tex. 492 (1849) (killer of trespassing mules civilly liable to their owner). But see Hummel v. State, 69 Okla. Crim. 38, 99 P.2d 913 (1940) (rancher was privileged to castrate a bull that threatened to impregnate pure-bred cows that were grazing on open-range). See generall' J. Ingham, The Law of Animais § 45 (1900); Annot., 12 A.L.R.3d 1103 (1967) (liability for accidentally or intentionally poisoning trespassing stock).

116. People v. Dunn, 39 Cal. App. 3d 418, 114 Cal. Rptr. 164 (1974).

117. See text accompanying notes 145-146 infra.

Self-help justice-occasionally organized on a group basis as vigilante justice-was a tradition in the nineteenth century American West. "The laws [in Wyoming] appeared to require that a farmer fence his land to keep cattle out, but many a farmer preferred to save the cost of a fence, then wait until cattle came in his land, and with a shot or two secure a winter's supply of beef." D. Boorstin, The Americans: The Democratic Experience 30 (1973). See also E. OsGooD, supra note 37, at 157-60 (lynching of horse thieves), at 242 (killing of trespassing cattle) \& at 252-53 (describing how large cattle companies mobilized an army to invade Johnson County, Wyoming, to prevent small ranchers from using violent self-help against the companies' cattle). 
formal relevance in public as well as private trespass law. Shasta County's law enforcement officials are entitled to impound cattle found running at large in closed range, but not those found in open range. ${ }^{18}$ Brad Bogue, the county Animal Control Officer, relies primarily on mediation and warnings when responding to reports of loose animals. Regardless of whether the trespass has occurred in open or closed range, Bogue's first priority is to locate the owner of the offending animals, and to ask him to retrieve the livestock promptly. For example, if the owner of a ranchette situated in open range were to complain of trespassing mountain cattle, Bogue would inform the complainant of the cattleman's rights in open range, but he would also find the owner of the animals and explain why it would be in the owner's interest to take better care of the livestock. Bogue asserts that little else is required in the usual case. In most years, Bogue's office does not impound a single head of cattle ${ }^{119}$ or issue a single criminal citation for failure to prevent cattle trespass. ${ }^{120}$

\section{Knowledge of Animal Trespass Law}

Before examining how Shasta County landowners actually resolve their cattle trespass disputes, I describe their working knowledge of the formal rules of trespass law. The extent of their knowledge is relevant for at least two reasons. First, Coase's Parable is set in a world of zero transaction costs, where everyone has perfect knowledge of legal rules. In reality, legal knowledge is imperfect because legal research is costly and

118. See Shasta County Ordinance Code $\S 3306$ (habitual animal trespasses declared to be a public nuisance, "provided that this section shall not apply to livestock upon the open range").

119. The Shasta County Animal Control Office's Monthly Reports for 1980-1982 indicate that the office impounded one "bovine" during that period-a stray animal that Bogue said was found within one block of the office's animal shelter. This figure understates the number of public impoundments, because the Brand Inspector on occasion may ship stray cattle to the Cottonwood Auction Yard, which is better equipped than the animal shelter to board livestock.

120. Robert Baker, the County District Attorney from 1965 to 1979 , could not recall a single criminal prosecution for cattle trespass on private lands. Gary Glendenning, the livestock specialist in the Detective's Division of the County Sheriff's Office, affirmed that criminal trespass actions were "never" brought, and that law enforcement officials mainly endeavored to identify and return the trespassing stock.

Criminal proceedings have been initiated against owners of stray livestock, however, when the stray animals have repeatedly posed serious risks to molorisls. See, e.g., State v. Whitlach, No. 82 CR 324 (Central Valley Just. Ct., Cal.) (misdemeanor action prompted by 26 telephone calls about cattle on roadways). 
human cognitive capacities are limited. The following overview of the working legal knowledge of Shasta County residents provides a glimpse at how people behave in the face of these constraints. Analysts interested in designing legal rules to achieve specific instrumental goals must heed data of this sort, because rules cannot have instrumental effects unless they are communicated to the relevant actors. Second, most residents resolve trespass disputes by applying lower-level norms that are consistent with an overarching norm of cooperation among neighbors. To the extent that residents understand that their lower-level norms are inconsistent with formal legal rules, the more notable it is that the norms prevail.

\section{Laymen's knowledge of trespass law.}

To apply formal legal rules to a specific trespass incident, a Shasta County resident would first have to know whether it had occurred in an open-range or closed-range area of the county. Ideally, the resident would either have or know how to readily locate the map of closed-range areas published by the county's Department of Public Works. Second, a legally sophisticated person would have a working command of the rules of trespass law that were presented in the prior subpart, and know how they vary from open to closed range.

I found no one in Shasta County-layman or professionalwith a complete working knowledge of the formal trespass rules just described. The persons best informed are, interestingly enough, two public officials without legal training: Brad Bogue, the Animal Control Officer, and Bruce Jordan, the Brand Inspector. ${ }^{121}$ Their jobs require them to deal with stray livestock on almost a daily basis. Both have striven to learn applicable legal rules, and both sometimes invoke formal law when mediating disputes between county residents. Both Bogue and Jordan possess copies of the closed-range map and relevant provisions of the California Code. What they do not know is the case law; for example, neither is aware of the rule that an intentional trespass is always tortious, even in open-range. Nevertheless, Bogue and Jordan, both familiar figures to the cattlemen and (to a lesser extent) the ranchette owners of rural Shasta County, have done

121. Bogue is a Shasta County employee; Jordan is an employee of the California Bureau of Livestock Identification. 
more than anyone else to educate the populace about formal trespass law.

What do ordinary rural residents know of that law? To a remarkable degree the landowners I interviewed did know whether their own lands were within open- or closed-range. Of the $25 \mathrm{I}$ asked to identify whether they lived in open or closed range, 21 provided the correct answer, including two who were fully aware that they owned land in both. ${ }^{122}$ This level of knowledge is probably atypically high. ${ }^{123}$ Most of the landowner interviews were conducted in the Round Mountain and Oak Run areas. The former was the site in 1973 of the Caton's Folly closed-range battle. More importantly, Frank Ellis' aggressive herding had provoked a furious closed-range battle in the Oak Run area just six months before I conducted the interviews. Two well-placed sources-the Oak Run postmaster and the proprietress of the Oak Run general store-estimated that this political storm had caught the attention of perhaps eighty percent of the area's adult residents. In the summer of 1982, probably no populace in the United States was more alert to the legal distinction between open- and closedrange than the inhabitants of Oak Run. ${ }^{124}$

What do laymen know of the substance of trespass law? In particular, what do they know of how the rules vary from open- to closed-range? Laymen tend to conceive of these legal rules in black-and-white terms: Either the livestock owners or the trespass victims "have the rights." We have seen that the law of animal trespass in open-range is quite esoteric. Even there, an animal owner is liable, for example, for intentional trespass, trespass through a lawful fence, or trespass by a goat. ${ }^{125}$ Only a few rural residents of Shasta County know anything of these subtleties. "Estray" and "lawful fence," central terms in the law of animal trespass, are not words in the cattlemen's everyday vocabulary. Neither of the two most sophisticated open-range ranchers that I interviewed were aware that enclosure by a lawful fence

122. Eleven correctly stated they lived in open-range; eight correctly stated they lived in closed-range; one gave a flatly wrong answer; one, a partially wrong answer; and two "didn't know."

123. My interviewees were disproportionately active in local politics; two had obtained copies of the Department of Public Works closed-range map in conjunction with their political endeavors.

124. Of 11 respondents asked, only three stated that they had known when they bought their land what kind of "legal range" it lay in.

125. See text accompanying notes 108-110 supra. 
elevates a farmer's rights to recover for trespass. A traditionalist, whose cattle had often caused mischief in the Northeastern Foothills, thought estrays could never be seized in open-range, although a lawful fence gives a trespass victim exactly that entitlement. No interviewee believed that Ellis' intentional herding on his neighbors' lands in open-range might have been in excess of his rights.

As most laymen in rural Shasta County see it, trespass law is clear and simple. In closed-range, an animal owner is strictly liable for trespass damages. (They of course never used, and would not recognize, the phrase "strict liability.") In open-range, their basic premise is that an animal owner is never liable. When I posed hypothetical fact situations designed to put their simple rules under stress, the lay respondents sometimes backpedaled a bit, but they ultimately stuck to the notion that cattlemen have the rights in open-range and trespass victims the rights in closedrange.

\section{Legal specialists' knowledge of trespass law.}

The laymen's penchant for simplicity enabled them to identify correctly the substance of the English rule on cattle trespass that formally applies in closed-range. In that regard, the laymen outperformed the "legal specialists"- the judges, attorneys, and insurance adjusters. Although I sought out specialists who I had reason to believe would be knowledgeable about rural legal problems, I found that in two important respects the legal specialists had a worse working knowledge of trespass and estray rules than did the lay landowners. ${ }^{126}$ First, in contrast to the landowners, the legal specialists immediately invoked negligence rules when asked to analyze rights in trespass cases. In general, they thought that a cattleman would not be liable for trespass in open-range (although about half seemed aware that this result would be affected by the presence of a lawful fence), and that he would be liable only when negligent in closed-range. The negligence approach has so dominated American tort law during this century that legal specialists-insurance adjusters in particularmay fail to identify narrow pockets where strict liability rules,

126. This startling finding can be attributed to the fact that trespass and estray claims are virtually never processed through the formal legal institutions of Shasta County. See text accompanying notes 151-160 infra. 
such as the English rule on cattle trespass, formally apply. ${ }^{127}$

Second, unlike the lay rural residents, the legal specialists knew almost nothing about the location of the closed-range districts in the county. ${ }^{128}$ For example, two lawyers who lived in rural Shasta County and raised livestock as a sideline, were ignorant of these boundaries; one incorrectly identified the kind of range in which he lived, and the other admitted he did not know what areas were open or closed. The latter added that this did not concern him because he would fence his lands under either legal regime.

I interviewed four insurance adjusters who settle trespassdamage claims in Shasta County. These adjusters had little working knowledge of the location of closed-range and open-range areas or of the legal significance of those designations. One incorrectly identified Shasta County as an entirely closed-range jurisdiction. Another stated that he did not keep up with the closed-range situation because "closed-range" just signifies places where there are fences, and the fence situation changes too rapidly to be worth following. The other two adjusters knew a bit more about the legal situation. Although neither possessed a closed-range map, they were able to guess how to locate one. On the other hand, both implied that they would not bother to find out whether a trespass incident had occurred in open- or closed-range before settling a claim. The liability rules that these adjusters apply to routine trespass claims seemed largely independent of formal law. ${ }^{129}$

\section{The Settlement of Trespass Disputes ${ }^{130}$}

If Shasta County residents were to act like the farmer and the

127. Some legal specialists conceivably may also believe that the negligence principle is in every application normatively superior to the principle of strict liability.

128. Additionally, neither of the two fence contractors interviewed had any notion of these boundaries. The county tax assessor assigned to the Oak Run-Round Mountain area was equally unfamiliar with the closed-range map.

129. In his study of the settlement of automobile-liability claims, Ross found the law-inaction to be simpler and more mechanical than the formal law, but he did not find it to be quite as disconnected as I found it in trespass cases. See H. Ross, supra note 12, at 134-35, 237-40. One might expect formal liability law to be particularly toothless when it applies to situations-such as animal trespass incidents-that generate few insurance claims, and for which the claims are almost always for paltry monetary amounts.

130. The scholars involved in the Civil Liability Research Project have attempted to standardize the vocabulary of dispute resolution. They use "grievance" to describe a perceived entitlement to pursue a claim against another, "claim" to describe a demand for 
rancher in Coase's Parable, they would settle their trespass problems in the following way. ${ }^{131}$ First, they would look to the formal law to determine who had what entitlements. They would then regard those substantive rules as beyond their influence ("exogenous" to use the economists' adjective). When they faced a potentially costly interaction, such as a trespass risk to crops, they would resolve it "in the shadow of" 132 the formal legal rules. Because transactions would be costless, enforcement would be complete: No violation of an entitlement would be ignored. For the same reason, two neighbors who interacted on a number of fronts would resolve their disputes front-by-front, rather than globally. My findings cast doubt on the realism of each of these implications of the Parable. Because Coase himself was fully aware that transactions are costly and thus that the Parable was no more than an abstraction, my findings in no way diminish his monumental contribution. ${ }^{133}$ The findings may, however, serve as a valuable caution to other law-and-economics scholars who may have underestimated the impact of transaction costs on how the world works. ${ }^{134}$

\section{Norms, not legal mules, are the basic sources of entitlements.}

In rural Shasta County, trespass conflicts are generally resolved not "in the shadow of the law" but, rather, beyond that shadow. Most rural residents are consciously committed to an overarching norm of cooperation among neighbors. ${ }^{135}$ In tres-

redress, and "dispute" to describe a rejected claim. See, e.g., Miller \& Sarat, Grievances, Claims, and Disputes: Assessing the Adversary Culture, 15 LAw \& Soc'y Rev. 525, 527 (1980-1981). I am less precise and employ these terms loosely, as they tend to be employed in ordinary speech.

131. See Coase, supra note 1 , at 15.

132. This now-familiar phrase originated in Mnookin \& Kormhauser, Bargaining in the Shadow of the Law: The Case of Divorce, 88 YALE L.J. 950 (1979).

133. See notes 3,13 supra and accompanying texts.

134. Law-and-economics scholars often employ models that explicitly assume that actors have perfect knowledge of legal rules. See, e.g., A. Polinsky, An InTroduction to Law and Economics 37-49 (1983) (assuming drivers and pedestrians know personal injury law); Shavell, An Analysis of Causation and the Scope of Liability in the Law of Torts, 9 J. LegaL Stud. 463, 471 (1980).

135. Although the rural landowners were emphatic about the importance of neighborliness and could offer many specific examples of neighborly behavior, they never articulated a general formula for how a rural resident should behave. In my forthcoming book on Shasta County I hypothesize that the specific norms they honored were wealth-maximizing, and explore how wealth-maximizing norms might evolve. See also text following note $161 \mathrm{infra}$.

For other discussions of the role of nonlegal norms in dispute settlement, see Eisenberg, Private Ordering Through Negotiation: Dispule-Settlement and Rulemaking, 89 HaRv. L. Rev. 637, $638-65$ (1976); Macaulay, supra note 12, at 61-62. 
pass situations, their salient lower-level norm, adhered to by all but a few deviants, is that an owner of livestock is responsible for the acts of his animals. Allegiance to this norm seems wholly independent of formal legal entitlements. Most cattlemen believe that a rancher should keep his animals from eating a neighbor's grass, regardless of whether the range is open or closed. Cattlemen typically couch their justifications for the norm in moral terms:

Marty Fancher: "Suppose I sat down [uninvited] to a dinner your wife had cooked." Dick Coombs: It "isn't right" to get free pasturage at the expense of one's neighbors. Owen Shellworth: "[My cattle] don't belong [in my neighbor's field]." Attorney-rancher Pete Schultz: A cattleman is "morally obligated to fence" to protect his neighbor's crops, even in open range.

The next several pages describe in greater detail how the norms of neighborliness operate and how deviants who violate these norms are informally controlled. These pages also identify another set of deviants: trespass victims who actually invoke their formal legal rights.

\section{Incomplete enforcement: the live-and-let-live philosophy.}

The norm that an animal owner should control his stock is modified by another norm that holds that a rural resident should "lump" minor damage stemming from isolated trespass incidents. The neighborly response to an isolated infraction is an exchange of civilities. A trespass victim should notify the animal owner that the trespass has occurred and assist the owner in retrieving the stray stock. Virtually all residents have telephones, the standard means of communication. A telephone report is regarded not as a form of complaint, but rather as a service to the animal owner, who, after all, has a valuable asset on the loose. Upon receiving a telephone report, a cattleman who is a good neighbor will quickly retrieve the animals (by truck if necessary), apologize for the occurrence, and thank the caller. The Mortons and the Shellworths, two ranching families in the Oak Run area particularly esteemed for their neighborliness, are known for promptly and apologetically responding to their neighbors' notifications of trespass. ${ }^{136}$

136. A trespass victim who cannot recognize the brand of the intruding animal-a quandary more common for ranchette owners than for ranchers-may telephone county authorities. Calls of this sort are eventually referred to the Brand Inspector or Animal Control 
Several realities of rural life in Shasta County help explain why residents are expected to lump trespass losses. First, it is commonplace for a country landowner to lose a bit of forage or to suffer minor fence damage. The area northeast of Redding lies on a deer migration route. During the late winter and early spring thousands of deer and elk move through the area, easily jumping the barbed wire fences. ${ }^{137}$ Because wild animals trespass so often, most rural residents come to regard minor damage from alien animals not as an injurious event, but as an inevitable part of life.

Second, most residents expect to be on both the giving and receiving ends of trespass incidents. Even the ranchette owners have, if not a few hobby livestock, at least several dogs, which they keep for companionship, security, and pest control. Unlike cattle, dogs that trespass may harass, or even kill, other farm animals. If trespass risks are symmetrical, and if residents lump all trespass losses, accounts balance in the long run. Under these conditions, the advantage of reciprocal lumping is that each person is made whole without having to expend time or money to settle disputes.

The norm of reciprocal restraint that underlies "live-and-letlive" also calls for ranchers to lump the costs of boarding another person's animal, even for months at a time. A cattleman often finds in his herd an animal wearing someone else's brand. If he recognizes the brand he will customarily inform its owner, but the two will often agree that the simplest solution is for the animal to stay put until the trespass victim next gathers his animals, an event that may be weeks or months away. The cost of "cutting" a single animal from a larger herd seems to underlie this custom. Thus, ranchers often consciously provide other people's cattle with feed worth perhaps as much as $\$ 10$ to $\$ 100$ per animal. Although Shasta County ranchers tend to regard themselves as financially pinched, even ranchers who know that they are legally entitled to recover feeding costs virtually never seek monetary compensation for boarding estrays. The largest

Officer, who, as mentioned, then regard their main priority to be return of the animal to its owner.

137. One rancher reported that during the winter he expects to find $30-40$ deer grazing in his hayfield each night. The owner of a particularly large ranch estimated that about 500 deer winter there-a condition he likes, because deer are "part of nature." John Woodbury, a key lobbyist for the passage of the Caton's Folly ordinance, stated that elk and deer had eaten more of the grass in his alfalfa field than mountain cattle ever had. 
ranchers northeast of Redding who were interviewed reported that they had never charged anyone, or been charged by anyone, for costs of that sort. Even when they do not know to whom a stray animal belongs, they put the animal in their truck the next time they take a load of animals to the auctionyard at Cottonwood, and drop it off without charge so that the Brand Inspector can locate the owner. ${ }^{138}$

3. The complexity of interneighbor relations: comprehensive mental accounts of who owes whom.

Residents with few animals may of course not perceive any average reciprocity of advantage in a live-and-let-live approach to animal trespass incidents. What if, for example, a particular rancher's livestock repeatedly caused minor mischief in a particular farmer's fields? In that situation, Shasta County norms call for the farmer to keep track of those minor losses in a mental account. Eventually, the norms entitle him to act to remedy any imbalance.

A fundamental feature of rural society makes this enforcement system feasible: Rural residents deal with one another on a large number of fronts, and most residents expect those interactions to continue far into the future. In sociological terms, their relationships are "multiplex," not "simplex."139 They interact on water supply, controlled burns, fence repairs, social events, staffing the volunteer fire department, and so on. Where population densities are low, each neighbor looms larger. Thus any trespass dispute with a neighbor is almost certain to be but one thread in the rich fabric of a continuing relationship.

A person in a multiplex relationship can keep a rough mental

138. Brand Inspector Bruce Jordan estimated that ranchers drop off approximately 300 head of stray livestock at the auctionyard each year, and that these ranchers typically decline to seek compensation from the owners of the strays.

139. See R. Kidder, Connecting Law and Society 70-72 (1983). The law and society literature has long emphasized that law is not likely to be important to parties enmeshed in a continuing relationship. For example, Marc Galanter has observed:

In the American setting, litigation tends to be between parties who are strangers.

Either they never had a mutually beneficial continuing relationship, as in the typical automobile case, or their relationship-marital, commercial, or organizational-is ruptured. In either case, there is no anticipated future relationship. In the American setting, unlike some others, resort to litigation is [usually] viewed as an irreparable breach of the relationship.

Galanter, Reading the Landscape of Disputes: What We Know and Don't Know (and Think I'e Know) About Our Allegedly' Contentious and Litigious Society, 31 U.C.L.A. L. Rev. 4, 24-25 (1983) (brackets in original). 
account of the outstanding credits and debits in each aspect of that relationship. ${ }^{140}$ Should the aggregate account fall out of balance, tension may mount because the net creditor may begin to perceive the net debtor as an overreacher. On the other hand, so long as the aggregate account is in balance, neither party need be concerned that particular subaccounts are not. For example, if a rancher were to owe a farmer in the trespass subaccount, the farmer can be expected to remain content if that imbalance were to be offset by a debt he owed the rancher in, say, the watersupply subaccount. ${ }^{141}$

The live-and-let-live norm also suggests that neighbors should put up with minor imbalances in their aggregate accounts, especially when they perceive that their future interactions will provide adequate opportunities for settling old scores. Creditors may prefer having others in their debt. For example, when Larry Brennan lost six to seven tons of baled hay to Frank Ellis' cattle in open range, Brennan (although he did not know it) had a strong legal claim against Ellis for intentional trespass. Brennan estimated his loss at between $\$ 300$ and $\$ 500$, hardly a trivial amount. When Ellis learned of Brennan's loss he told Brennan to "come down and take some hay" from Ellis' barn. Brennan declined this offer of compensation, partly because he thought he should not have piled the bales in an unfenced area, but also because, to paraphrase his words, he would rather have Ellis in debt to him than be in debt to Ellis. Brennan was willing to let Ellis run up a deficit in their aggregate interpersonal accounts because he thought that as a creditor he would have more leverage over Ellis' future behavior.

\section{The control of deviants: the key role of self-help.}

The rural Shasta County population includes deviants who do not adequately control their livestock and do not adequately bal-

140. Cf. A. Vidich \& J. Bensman, Small Town in Mass Society 34 (rev. ed. 1968):

To a great extent these arrangements between friends and neighbors have a reciprocal character: a man who helps others may himself expect to be helped later on. In a way the whole system takes on the character of insurance. Of course some people are more conscious of their premium payments than others and keep a kind of mental bookkeeping on "what they owe and who owes them what," which is a perfectly permissible practice so long as one does not openly confront others with unbalanced accounts.

141. See O. Williamson, Markets and Hierarchies 256-57 (1975) (a party to a continuing relationship seeks to achieve a favorable balance in the overall set of interactions, not in each separate interaction). 
ance their informal accounts with their neighbors. Frank Ellis, for example, seemed to care little about his reputation among his neighbors. In general, the traditionalists who let their animals loose in the mountains during the summer are less scrupulous than the modernists are in honoring the norms of neighborliness, perhaps because the traditionalists have less complex, and shorter-lived, interrelationships with the persons who encounter their range cattle.

To discipline deviants, the residents of rural Shasta County use the following four types of countermeasures, listed in escalating order of seriousness: (1) self-help retaliation; (2) reports to county authorities; (3) claims for compensation informally submitted without the help of attorneys; and (4) formal legal claims to recover damages. The law starts to gain bite as one moves down this list.

Self-help. Because most trespass disputes in Shasta County are resolved according to extralegal rules, the fundamental enforcement device is also extralegal. A measured amount of self-helpjust enough to "get even," to invoke a marvelously apt phraseis the predominant and ethically preferred response to someone who has not taken adequate steps to prevent his animals from trespassing. ${ }^{142}$

The mildest form of self-help is negative gossip. ${ }^{143}$ This usually works because only the extreme deviants are immune from the general obsession with neighborliness. Although the Oak Run-Round Mountain area is undergoing a rapid increase in population, it remains distinctly rural in atmosphere. People tend to know one another, and they value their reputations in the community. Some ranching families have lived in the area for several generations and plan to stay indefinitely. Members of these families seem particularly intent on maintaining their reputations as good neighbors. Should one of them not promptly and courteously retrieve an estray, he might fear that any resulting gossip would permanently besmirch the family name.

Residents of the Northeastern Foothills seem quite conscious of the role of gossip in their system of social control. One longtime resident, who had also lived for many years in a suburb of a

142. See generally Black, Crime as Social Control, 48 AM. Soc. Rev. 34 (1983) (a trenchant assessment of the phenomenon of self-help).

143. See Merry, Rethinking Gossip and Scandal, in 1 Toward a General Theory of Social ConrRol 271 (D. Black ed. 1984). 
major California urban area, observed that people in the Oak Run area "gossip all the time," much more than in the urban area. Another reported intentionally using gossip to sanction a traditionalist who had been "impolite" when coming to pick up some stray mountain cattle; he reported that application of this self-help device produced an apology, an outcome itself presumably circulated through the gossip system.

The furor over Frank Ellis' loose cattle in the Oak Run area induced area residents to try a sophisticated variation of the gossip sanction. The ranchette residents who were particularly bothered by Ellis' cattle could see that he was utterly indifferent to his reputation among them. On the other hand, they thought that a large rancher such as Ellis would worry about his reputation among the large cattle operators in the county. They therefore reported Ellis' activities to the Board of Directors of the Shasta County Cattlemen's Association. This move proved unrewarding, for Ellis was also surprisingly indifferent to his reputation among the cattlemen. As the Association President later explained in a hearing before the county Board of Supervisors, the problem was that Ellis, a county resident for a decade, "hasn't been [in the County] all that long."144

When milder measures such as gossip fail, a person is regarded as being justified in threatening to use, and perhaps even actually using, tougher self-help sanctions. Particularly in unfenced country, a victim may respond to repeated cattle trespasses by herding the offending animals to a location extremely inconvenient for their owner. ${ }^{145}$ Another common response to repeated trespasses is to threaten to kill a responsible animal should it ever enter again. Although the killing of trespassing livestock is a crime in California, ${ }^{146}$ six landowners-not noticeably less civilized than the others-unhesitatingly volunteered that they had issued death threats of this sort. These threats are credible in Shasta County, because victims of recurring trespasses, particularly if they have first issued a warning, feel justified in killing or injuring the mischievous animals. Despite the criminality of the conduct (a fact not necessarily known to the

144. See note 75 supra.

145. Two respondents admitted that they had done this. For some scattered precedents on the legality of this practice, see note 114 supra.

146. Cal. Penal Code $\S 597$ (a) (West Supp. 1985); People v. Dunn, 39 Cal. App. 3d 418, 114 Cal. Rptr. 164 (1974). 
respondents), I learned the identity of two persons who had shot trespassing cattle. Another landowner told of running the steer of an uncooperative neighbor into a fence. The most intriguing report came from a rancher who had had recurrent problems with a trespassing bull many years ago. This rancher told a key law enforcement official that he wanted to castrate the bull-"to turn it into a steer." The official replied that he "would have deaf ears" if that were to occur. The rancher asserted that he then carried out his threat.

It is difficult to estimate how frequently rural residents actually resort to violent self-help. Nevertheless, fear of physical retaliation is undoubtedly one of the major incentives for order in rural Shasta County. Ranchers who run herds at large freely admit that they worry that their trespassing cattle might meet with violence. One traditionalist reported that he is responsive to complaints from ranchette owners because he fears they will poison or shoot his stock. A judge for a rural district of the county asserted that a vicious animal is likely to "disappear" if its owner does not control it. A resident of the Oak Run area stated that some area residents responded to Frank Ellis' practice of running herds at large by rustling Ellis' cattle. He suggested that Ellis prepare a teeshirt with the following inscription: "Eat Ellis Beef. Everyone in Oak Run Does!"

Complaints to public officials. ${ }^{147}$ The long-time ranchers of Shasta County pride themselves on being able to resolve their problems on their own. Except when they lose animals to rustlers, they do not seek help from public officials. Although ranchette owners also use the self-help remedies of gossip and violence, they, unlike the cattlemen, sometimes respond to a trespass incident by contacting a county official who they think will remedy the problem. These calls are usually funneled to the Animal Control Officer or Brand Inspector, who report that most of their callers are ranchette owners with limited rural experience. As already discussed, these calls do produce results. The county officials typically contact the owner of the animal, who then arranges for its removal. Brad Bogue, the Animal Control Officer, reported that in half the cases the caller knows whose animal it is. This suggests that callers often think that requests

147. Cf. Engel, Cases, Confict, and Accommodation: Patterns of Legal Interaction in an American Community, 1983 Am. B. Found. Research J. 803, 821 (role of complaints to public officials in a rural Illinois county). 
for removal have more effect when issued by someone in authority.

Mere removal of an animal may provide only temporary relief if its owner is a mountain lessee whose cattle repeatedly descend upon the ranchettes. County officials therefore use mild threats to caution repeat offenders. In closed-range, they may mention both their power to impound the estrays and the risk of criminal prosecution. These threats appear to be bluffs; the County never impounds stray cattle when it can locate an owner, and it rarely prosecutes cattlemen (and then only when their animals have posed risks to motorists). ${ }^{148}$ In open-range, county officials may deliver a more subtle threat: not that they will initiate a prosecution, but that, if the owner does not mend his ways, the Board of Supervisors may face insuperable pressure to close the range in the relevant area. Because cattlemen perceive that a closure significantly diminishes their legal entitlements in situations where motorists have collided with their livestock, this threat can catch their attention.

A trespass victim's most effective official protest is one delivered directly to his elected county supervisor-the person best situated to change stray-cattle liability rules. Many Shasta County residents are aware that traditionalist cattlemen fear the supervisors more than they fear law enforcement authorities. Thus in 1973, alfalfa farmer John Woodbury made his repeated phone calls about mountain cattle not to Brad Bogue but to Supervisor John Caton. ${ }^{149}$ When a supervisor receives many calls from trespass victims, his first instinct is to mediate the crisis. Former supervisor Norman Wagoner's standard procedure was to assemble the ranchers in the area and advise them to put pressure on the offender or else risk the closure of the range. Wagoner's successor, Supervisor John Caton, similarly told Frank Ellis that he would support a closure at Oak Run unless Ellis built three miles of fence along the Oak Run Road. If a supervisor is not responsive to a constituent's complaint, the constituent may respond by circulating a closure petition. ${ }^{150}$

The rarity of claims for monetary relief. Because Shasta County residents tend to settle their trespass disputes beyond the

148. See notes 119-120 supra and accompanying text.

149. See text following note 68 supra.

150. This was how Doug Heinz goaded Supervisor John Caton into action at Oak Run. See text accompanying note 72 supra. 
shadow of the law, one might expect that the norms of neighborliness would include a norm against the invocation of formal legal rights. And this norm is indeed strongly established.151 Owen Shellworth: "I don't believe in lawyers [because there are] always hard feelings [when you litigate]." Tony Morton: "[I never press a monetary claim because] I try to be a good neighbor." Norman Wagoner: "Being good neighbors means no lawsuits." Although trespasses are frequent, Shasta County's rural residents virtually never file formal trespass actions against one another. John Woodbury, for example, made dozens of phone calls to Supervisor John Caton, but never sought monetary compensation from the traditionalists whose cattle had repeatedly marauded his alfalfa field. Court records and conversations with court clerks indicate that in most years not a single private lawsuit is filed in the county's courts seeking damages for either trespass by livestock or the expense of boarding estrays. ${ }^{152}$ The residents of the Northeastern Foothills not only refrain from filing formal lawsuits, but they are also strongly disinclined to submit informal monetary claims to an owner of trespassing animals or that owner's insurance company. ${ }^{153}$

The landowners who were interviewed clearly regard their restraint in seeking monetary relief as a mark of virtue. When asked why they did not pursue meritorious legal claims arising from trespass or fence-finance disputes, various landowners replied: "I'm not that kind of guy;" "I don't believe in it;" "I don't like to create a stink;" "I try to get along." The landowners who attempted to provide a rationale for this forbearance all implied the same one, a long-term reciprocity of advantage. Ann Kershaw: "The only one that makes money [when you litigate] is the lawyer." Al Levy: "I figure it will balance out in the long run."

151. Investigators have found norms against litigation in other social environments. See Engel, supra note 147, at 816-22, 851-56 (rural Illinois county); Macaulay, supra note 12, at 64 (Wisconsin businessmen).

152. In the Burney Justice Court, the 1980 small claims files showed no animal trespass cases, and the clerks could recall no such cases in their four years on the job.

In the Central Valley Justice Court, no small claims for the 8/81 to 6/82 period involved animal trespass, and the civil clerk who had worked there for 11 years could not remember any. The index of defendants for the 1975-82 period indicated that Frank Ellis was the only large rancher to become the target of any kind of legal action. See text accompanying notes 155-160 infra.

153. I did hear several secondhand reports of informally settled claims for the costs of boarding estrays. Only one rancher told of paying such a claim; he regarded the claimant's pursuit of the money as a "cheap move." 
Pete Schultz: "I hope they'll do the same for me." Phil Ritchie: "My family believes in 'live and let live." "

Mutual restraint saves parties with long-term relationships the costs of going through the formal claims process. Adjoining landowners who practice live-and-let-live are both better off whenever the negative externalities from their activities are roughly in equipoise. Equipoise is as likely in closed-range as in open. Landowners with property in closed-range-the ones with the greatest formal legal rights-were the source of half of the quotations in the prior two paragraphs.

Shasta County landowners regard a monetary settlement as an arms-length transaction that symbolizes an unneighborly relationship. Should your goat happen to eat your neighbor's tomatoes, the neighborly thing for you to do would be to help replant the tomatoes; a transfer of money would be too cold and too impersonal. ${ }^{154}$ When Kevin O'Hara's cattle went through a break in a fence and destroyed his neighbor's corn crop (a loss of less than $\$ 100$ ), O’Hara had to work hard to persuade his neighbor to accept O'Hara's offer of money damages. O'Hara insisted on making this payment because he "felt responsible" for his neighbor's loss, a feeling that would not have been in the least affected had the event occurred in open- instead of closed-range. There can also be social pressure against offering money settlements. Bob Bosworth's father agreed many decades ago to pay damages to a trespass victim in a closed-range area just south of Shasta County; other cattlemen then rebuked him for setting an unfortunate precedent. The junior Bosworth, currently President of the Shasta County Cattlemen's Association, could recall no other out-of-pocket settlement in a trespass case.

Trespass victims who sustain an unusually large loss are more likely to take the potentially deviant step of making a claim for monetary relief. I interviewed adjusters for the two insurance companies whose liability policies would be most likely to cover losses from animal trespass. The adjusters' responses suggest that in a typical year these companies receive fewer than ten trespass damage claims originating in Shasta County. In the paradig-

154. A donor who wishes to symbolize an intimate relationship typically gives, not currency, but a gift that apparently required special effort to prepare. See Landa, The Enigma of the Kula Ring: Gifl-Exchanges and Primilive Law and Order, 3 INT'L REv. L. \& Econ. 137, 152 (1983) (Melanesians return armshells for necklaces because to return a necklace for a necklace would be interpreted as a rejection of friendship). See generally M. MAuss, The GrFT (1967). 
matic case, the insured is not a rancher, but rather a ranchette owner whose family's horse escaped and trampled a neighboring homeowner's shrubbery. The claimant is typically not represented by an attorney-a type of professional these adjusters rarely encounter. The adjusters also settle each year two or three trespass claims that homeowners or ranchette owners have brought against ranchers. Ranchers who suffer trespasses virtually never file claims against others' insurance companies. An adjuster for the company that insures most Shasta County ranchers stated that he could not recall, in his twenty years of adjusting, a single rancher's claim for compensation for trespass damage.

The landowners, particularly the ranchers, express a strong aversion to hiring an attorney to fight one's battles. To hire an attorney is to escalate a conflict. A good neighbor does not do such a thing because the "natural working order" calls for two neighbors to work out their problems between themselves. The files in the Shasta County courthouses reveal that the ranchers who honor norms of neighborliness-the vast majority-are simply not involved in cattle-related litigation of any kind.

My field research uncovered two instances in which animal trespass victims in the Oak Run-Round Mountain area had turned to attorneys. In one of these cases the victim actually filed a formal complaint. Because attorney-backed claims are so unusual, these two disputes deserve elaboration.

The first dispute involved Tom Hailey and Curtis McCall. For three generations, Hailey's family has owned a large tract of foothill forest in an open-range area near Oak Run. In about 1978, Hailey discovered McCall's cattle grazing on some of Hailey's partially fenced land. Hailey suspected that McCall had brought the animals in through a gate in Hailey's fence. When Hailey confronted him, McCall, who lived about a mile away, acted as if the incursion had been accidental. Hailey subsequently found a salt block on the tract-an object he could fairly assume that McCall had put there to service his herd. Hailey thus concluded that McCall had not only deliberately trespassed, but had also aggravated the offense by untruthfully denying the charge. Hailey seized the salt block and consulted an attorney, who advised him to seek compensation from McCall. The two principals eventually agreed to a small monetary settlement.

Hailey is a semi-retired government employee who spends much of his time outside of Shasta County; he is regarded as re- 
clusive and eccentric-certainly someone outside the mainstream of Oak Run society. McCall, a retired engineer with a hard-driving style, moved to Shasta County in the late 1970 s to run a small livestock ranch. The Haileys refer to him as a "Texan"-a term that connotes someone who is both an outsider and lacks neighborly instincts.

The second dispute involved Doug Heinz and Frank Ellis. As already noted, Heinz had the misfortune of owning a ranchette near Ellis' ranch. ${ }^{155}$ After experiencing repeated problems with Ellis' cattle, Heinz unilaterally seized three of the animals that had broken through his fence. Heinz boarded these animals for three months without notifying Ellis. Heinz later asserted he intended to return them when Ellis next held a roundup. According to Heinz, Ellis eventually found out that Heinz had the animals and asked for their return. Heinz agreed to return them if Ellis would pay pasturage. When Ellis replied, "You know I'm good for it," Heinz released the animals and sent Ellis a bill. Ellis refused to pay the bill, and he further infuriated Heinz by calling him "boy" whenever Heinz brought up the debt.

On January 8, 1981, Heinz filed a small-claims action against Ellis to recover $\$ 750$ "for property damage, hay and grain ate [sic] by defendant's cattle, boarding of animals."156 Acting through the attorney he kept on retainer, Ellis responded eight days later with a separate civil suit against Heinz. ${ }^{157}$ Ellis's complaint sought $\$ 1,500$ compensatory and $\$ 10,000$ punitive damages from Heinz for the shooting deaths of two Black Brangus cows that Ellis had pastured on BLM lands; it also sought compensation for the weight loss Ellis' three live animals had sustained during the months Heinz had been feeding them. The two legal actions were later consolidated. Heinz, who called Ellis' allegation that Heinz had killed two cows "100 percent lies" and "scare tactics," hired a bright young Redding attorney to represent him. This attorney threatened to pursue a malicious prosecution action against Ellis if Ellis persisted in asserting that Heinz had slain the Black Brangus cows. In December 1981, the parties agreed to a settlement under the terms of which Ellis paid Heinz $\$ 300$ in damages and $\$ 100$ for attorney fees. Ellis' insurance company picked up the tab. By that time Heinz was

155. See text following note 70 supra.

156. Heinz v. Ellis, No. 81 SC 7 (Cent. Valley Just. Ct. filed Jan. 8, 1981).

157. Ellis v. Heinz, No. 81 CV 6 (Cent. Valley Just. Ct. filed Jan. 16, 1981). 
spearheading a political campaign to close the range Ellis had been using. ${ }^{158}$

The Heinz-Ellis and Hailey-McCall disputes share several characteristics. Although both arose in open range, in each instance legal authority favored the trespass victim: Hailey, because McCall's trespass had been intentional; and Heinz, because Ellis' animals had broken through an apparently lawful fence. ${ }^{159}$ In both instances, the victim, before consulting an attorney, had attempted to obtain informal satisfaction but had been rebuffed. Each victim perceived that the animal owner had not been honest. Each dispute was ultimately settled in the victim's favor. In both instances, neither the trespass victim nor the cattle owner was well-socialized in rural Shasta County norms. Thus other respondents tended to refer to the four individuals involved in these two claims as "bad apples," "odd ducks," or otherwise as people not aware of the natural working order. Ordinary people, it seems, do not often turn to attorneys to help resolve disputes. ${ }^{160}$

\section{SUmmary AND Implications}

Coase's Parable of the Farmer and the Rancher, like most writing in law and economics, implies that disputants look solely to formal legal rules to determine their entitlements. In rural Shasta County, California, residents instead typically look to informal norms to determine their entitlements in animal trespass situations. In open-range areas, the norm that a livestock owner should supervise his animals dominates the legal rule that a cattleman is not legally liable for unintentional trespasses on unfenced land. Trespass victims mainly employ negative gossip and physical reprisals against trespassing stock to discipline cattlemen who violate this norm.

In Shasta County, the law of trespass had no apparent feed-

158. See text accompanying notes 71-76 supra.

159. Heinz had technically imperiled his statutory claim for damages under the Estray Act when he failed to notify the proper public authorities promptly that he had taken up Ellis' animals. See CaL. Agric. Code $\S \S 17042,17095$ (West 1967).

160. See also W. Nelson, Dispute and Conflict Resolution in Plymouth Colony, MASSACHUSETTS 1725-1825 (1981) (Plymouth's particularly litigious individuals during the 1725-1774 period tended to be people who were poorly socialized); Todd, Litigious Marginals: Character and Disputing in a Bavarian Iillage, in The Disputing Process: LAW IN Ten Societies, supra note 12, at 86, 118 (socially marginal people were disproportionately represented in civil and criminal litigation). 
back effects on trespass norms. In no instance did the legal designation of an area as open (or closed) range affect how residents resolved a trespass or estray dispute. Thus Rancher Kevin O'Hara paid a neighbor for the loss of a corn crop because he "felt responsible," a feeling he said would not have been influenced by formal trespass law. Being located in closed range did not appear to make a trespass victim more likely to perceive a grievance or to exercise self-help. Insurance adjusters paid virtually no attention to the distinction between open-range and closed-range when settling trespass claims.

Other findings suggest the unreality of other literal features of the Coasean Parable. Victims of stray cattle did not treat the formal legal rules as exogenous; they were aware that one way to use limited resources is to lobby for legal change. Victims' enforcement of their norm-based entitlements was far from complete; they ignored some trespasses altogether and used others to offset outstanding informal debts. Victims tended to shun monetary settlements and instead preferred in-kind transfers, including ones effected through self-help. Although these findings are at odds with the literal features of the Coasean Parable, they are fully consistent with Coase's central idea that, regardless of the specific content of law, people tend to structure their affairs to their mutual advantage.

The Shasta County evidence suggests that law and economics scholars need to pay more heed to how transaction costs influence the resolution of disputes. Because it is costly to carry out legal research and to engage in legal proceedings, a rational actor often has good reason to apply informal norms, not law, to evaluate the propriety of human behavior. Contracts scholars have long known that norms are likely to be especially influential when disputants share a continuing relationship. ${ }^{161}$ A farmer and a rancher who own adjoining lands are enduringly intertwined, and therefore readily able to employ nonlegal methods of dispute resolution. Law-and-economics scholars misdirect their readers and students when they invoke examples-such as the Parable of the Farmer and the Rancher-that greatly exaggerate the domain of human activity upon which the law casts a shadow.

This article will be incorporated into a forthcoming book on

161. See, e.g., Macaulay, supra note 12; Macneil, The Many Futures of Contracts, 47 S. CaL. L. Rev. 691,715 (1974). 
dispute resolution among neighbors. Other parts of the book will describe how Shasta County residents resolve disputes over both the financing of boundary fences and the allocation of losses stemming from vehicle-livestock collisions on highways. The book will explain why proposed closed-range ordinances generate so much political heat in Shasta County even though trespass law is itself practically irrelevant. Finally and more ambitiously, in the book I will use the Shasta County data as a springboard to develop a theory of the content and role of norms. Building on recent work in game theory, I hypothesize that, in the absence of identified "social imperfections," the norms that govern the relations among members of a group tend to maximize the aggregate wealth of group members. The book will explore the normative and positive implications of this theory for the interplay between the legal system and more informal systems of social control. 
